\title{
A Critical Analysis of Post-Conviction Review in New South Wales, Australia
}

\author{
Rhanee Rego ${ }^{1}$ \\ Ph.D Candidate, Newcastle Law School \\ The University of Newcastle \\ N.S.W., Australia
}

Wrongful convictions leave an indelible mark on society. They are a tangible demonstration that the criminal legal system has failed, and a poignant reminder that all human institutions are fallible. Robust post-conviction review mechanisms are essential to provide an opportunity for justice to be achieved eventually for those who are wrongfully convicted. Through a critical examination of the post-conviction review mechanisms in NSW, which includes determining the existence of independence, transparency and accountability in the system, some deficiencies will be identified and analysed. Drawing on insights from the author's role as a lawyer for Kathleen Folbigg (a woman convicted in 2003 of the murder of three of her infant children, and the manslaughter of her first child), this article will outline some of the key problems with the current system of post-conviction review in NSW. It then critically compares the existing system with the United Kingdom Criminal Cases Review Commission ("UK CCRC"). The UK CCRC has been chosen because it is a pioneering model which is designed to identify and remedy wrongful convictions in an independent, transparent, and accountable way. The article concludes that a body similar to the UK CCRC should be implemented in NSW to achieve justice for those wrongfully convicted.

Faculty Endorsement: Amy Maguire, Associate Professor, Newcastle Law School, The University of Newcastle, Australia. I endorse this article for publication in the Wrongful Conviction Law Review.

I. Introduction

II. Post-Conviction Review in NSW

A. A Petition to the Governor

B. An Application to the Supreme Court

C. An Inquiry as an Outcome Arising from a Petition to the Governor and an Application to the Supreme Court

III. Justice as Fairness: Independence, Transparency and Accountability

A. Independence

B. Transparency

C. Accountability

IV. Some Key Criticisms of Post-Conviction Review in NSW

V. The Folbigg Case

\footnotetext{
${ }^{1}$ Rhanee Rego is a solicitor of the New South Wales Supreme Court and the High Court of Australia. She is in private practice. Rhanee is also a Sessional Academic and $\mathrm{PhD}$ candidate at The University of Newcastle Law School, NSW, Australia.
} 
VI. The Issues with the Review in Ms. Folbigg's Case

A. A Lack of Legal Timeframes

B. Selection of Commissioner and Counsel Assisting

C. The Commissioner's Broad Discretion in the Inquiry Process

a. Scope of Inquiry

b. "Hot Tubbing" Experts and Treatment of Expert Witnesses

c. Redactions of Evidence

d. Refusal to Consider Ms. Folbigg's Diaries in Context

e. Leave to Appear at Inquiry

f. Not Reopening Hearings to Hear Further Evidence

D. Independence, Transparency and Accountability in Ms. Folbigg's case?

VII. The United Kingdom's Criminal Cases Review Commission

VIII. NSW v UK: How do the Systems Compare?

IX. Recommendations

X. Conclusion

\section{Introduction}

There is no worse injustice than "when the law turns upon itself and convicts an innocent person."2 This has a significant impact on society: it is a recognition that the criminal legal system has failed in a substantial way. Many factors contributing to wrongful convictions (e.g., prosecutorial misconduct or errors in forensic science) are now well recognised and understood. ${ }^{3}$ There is, however, very little known about how the system of post-conviction review - directed to remedying those failings of the criminal justice system - operates in New South Wales (NSW), Australia. ${ }^{4}$ The process for reviewing wrongful convictions is afforded to the executive government to engage in a process that lacks significant independence, transparency, and accountability. Unlike other common law countries, such as the United Kingdom where a Criminal Cases Review Commission ("UK CCRC") has been established, ${ }^{5}$ there is no independent body tasked with investigating wrongful convictions in NSW. There are no well-funded and appropriately scaled innocence projects as in various jurisdictions of the United States. Consequently, there is no appropriate pathway available for review of wrongful convictions in NSW, and there is a significant risk that such cases will go unidentified and unremedied.

This article is a critical analysis of the system of post-conviction review in NSW. It is intended to be an introduction to analysing the structure and function of the system. It does not consider the factors which cause or contribute to wrongful convictions such as errors in forensic science or police misconduct. The article will first provide a background to the post-conviction

${ }^{2}$ Van der Meer $v$ The Queen, [1988] 82 ALR 10, Reasons of Deane J, at para 7 [Van der Meer].

${ }^{3}$ Australian Academy of Science, "It is profoundly wrong to deny justice by denying science," (29 August 2021), online: $<$ https://www.science.org.au/news-and-events/news-and-media-releases/it-isprofoundly-wrong-to-deny-justice-by-denying-science> $[A A S]$.

${ }^{4}$ New South Wales is the most populous Australian state.

5 A CCRC has also been established in Scotland, Norway, and New Zealand. In early 2021, it was announced that Canada is taking steps to establish its own Commission. 
review system in NSW and offer some criticisms. It then provides a theoretical framework to evaluate post-conviction review: the notion of justice as fairness. In this context, justice and therefore fairness, is measured through three key elements: independence, transparency, and accountability.

Kathleen Folbigg's case is then used to demonstrate how the system works in practice. In 2003, Ms. Folbigg was convicted of the murder of three of her infant children - Patrick, Sarah, and Laura - and the manslaughter of her firstborn, Caleb. Each died at different times over a period of 10 years. The prosecution claimed that Ms. Folbigg smothered her four children in a state of stress/rage. There was no evidence from the children's autopsies to indicate smothering or inflicted harm to any of them. The prosecution focused heavily on cherry-picked entries from Ms. Folbigg's private diaries, which were said to constitute confessions of murder. ${ }^{6}$ Ms. Folbigg is now serving her $19^{\text {th }}$ year of prison. At present she awaits a decision by the Attorney General of NSW on whether he will recommend to the Governor that she should be pardoned and released. The petition requesting her immediate release is based largely on new genetic findings for Sarah and Laura Folbigg. It has been supported by approximately 150 leading researchers and practitioners in science and medicine. Nobel Laureate and world-renowned scientist Professor Elizabeth Blackburn has said, in support of the petition, that "[i]t is profoundly wrong to deny justice by denying science."7

Part of the analysis is based on the author's insights as a lawyer who worked for Ms. Folbigg in the post-conviction review system. The article will focus disproportionately on inquiries as the mode of review (as was ordered in Ms. Folbigg's case) to highlight some of the previously unknown ways in which NSW post-conviction review operates. ${ }^{8}$ A critical comparison between the review system in NSW and the UK CCRC will then be used to outline, theoretically, how Ms. Folbigg's case might have been dealt with by the latter. This article ultimately concludes that a

\footnotetext{
${ }^{6}$ However, expert opinions on the diaries recently obtained by the author and her colleague on behalf of Ms. Folbigg (these reports being the first of their kind in the history of this case) conclude that the diaries cannot be taken as confessions of murder or harm to her children, and do not show any signs of buried hostility or rage towards her children. They conclude that diaries and journals are not for anyone else to interpret except the author. Any interpretations by others are highly likely to be wrong, see The Daily Telegraph, "New Recording of Kathleen Folbigg talking about her children," (9 October 2021), online: <https://www.dailytelegraph.com.au/truecrimeaustralia/crimeinfocus/new-recording-of-kathleen-folbiggtalking-about-her-children/news-story/74a7df10aebe46a0359460c9625fa164>[Daily Telegraph].

60 Minutes Australia aired an update program on Kathleen Folbigg's case on 21 November 2021 which reports on the new expert analyses on the diaries, online:

<https://www.youtube.com/watch?v=hCQyfPhg7uA $><$ https://www.youtube.com/watch?v=4CArRdiNH HE>

[60 Minutes].

${ }^{7}$ AAS, supra at note 3 .

${ }^{8}$ The author acknowledges that not all cases subject to post-conviction review, and more specifically, a petition to the Governor, would necessarily occur in the same way or confront the same issues. Although, a conclusion that can be reasonably drawn is that there is a deficiency in law and process, which allowed the below identified issues to occur in Kathleen Folbigg's case.
} 
Criminal Cases Review Commission ("CCRC") is a preferable method of review to that which currently exists in NSW and suggests that NSW implement something like it.

\section{Post-conviction review in NSW}

Australia has a Westminster system of government ${ }^{9}$ like the United Kingdom and Canada. The United Kingdom once had post-conviction review mechanisms almost identical to those of NSW. ${ }^{10}$ Canada still has very similar review processes, but reform is underway to establish a CCRC. ${ }^{11}$

The history of post-conviction review in NSW can be traced back to the Criminal Law Amendment Act 1883 (NSW) ${ }^{12}$ and later, to the Crimes Act 1900 (NSW). ${ }^{13}$ There is no comprehensive history prior to this time. ${ }^{14}$ The provisions in the preceding legislation were in all material respects the same as the current legislation; very little has changed between the first recorded legislation on post-conviction review to now. Before the current Crimes (Appeal and Review) Act 2001 (NSW) ("the Act"), the spotlight was on the post-conviction system review due to a series of wrongful convictions: Lindy Chamberlain; Kelvin Condren; Alexander McLeodLindsay; Ziggy Pohl; and Arthur Loveday. ${ }^{15}$ At the time, there was a "general climate of public concern" about wrongful convictions in Australia and elsewhere, especially in the United Kingdom. ${ }^{16}$

${ }^{9}$ See e.g., Jack Richardson, Australia's Constitutional Government (Chatswood DC, Australia: LexisNexis Butterworths, 2016); RAW Rhodes, Comparing Westminster (Oxford: Oxford University Press, 2009).

${ }^{10}$ Carolyn Hoyle \& Mai Sato, Reasons to Doubt: Wrongful Convictions and the Criminal Cases Review Commission (Oxford: Oxford University Press, 2019) at 3-7 [Hoyle \& Sato].

${ }^{11}$ Department of Justice Canada, Minister of Justice and Attorney General of Canada takes important step toward creation of an independent Criminal Case Review Commission, online:

<https://www.canada.ca/en/department-justice/news/2021/03/minister-of-justice-and-attorney-general-ofcanada-takes-important-step-toward-creation-of-an-independent-criminal-case-review-commission.html>. ${ }^{12}$ ss 383 and 384.

${ }^{13}$ s 475 .

${ }^{14}$ For a brief account of the history see, Eastman v Director of Public Prosecutions (ACT) (2003), 214 CLR 318.

${ }^{15}$ For more information on Lindy Chamberlain: see generally, Katherine Biber, "Evidence in the museum: Curating a miscarriage of justice" (2018) 22:4 Theor Criminol 505; Kelvin Condren: see generally, Rachel Dioso-Villa, "'Out of grace': Inequity in post-exoneration remedies for wrongful conviction" (2014) 37:1 UNSW LJ 349; Alexander McLeod-Lindsay: see generally, Malcolm Brown \& Paul Wilson, Justice and nightmares: successes and failures of forensic science in Australia and New Zealand (Sydney, NSW, Australia: New South Wales University Press, 1992); Ziggy Pohl: see generally, Bernie Matthews, "Australian Miscarriages of Justice" (2004) 10 Nat' Legal Eagle 14 at 15; Arthur Loveday: see generally, Yvonne Swift, "Section 475 Inquiry - The Last Resort" (1993) 5:1 CICJ 93.

${ }^{16}$ David Brown, "Review of Section 475 of the Crimes Act 1900: The Attorney General's Issue Paper" (1993) 5:1 CICJ 85. About this time the United Kingdom was reflecting on their own system of post- 
Post-conviction review is now governed by Part 7 of the Act which is entitled "[r]eview of convictions and sentences." Part 7 contains two pathways that can be used by a convicted person to seek review: a petition to the Governor for a review of a conviction or sentence; ${ }^{17}$ and an application to the Supreme Court. ${ }^{18}$ There is also one further pathway available to a convicted person: a petition to the Governor to exercise the Royal Prerogative of Mercy (to issue a pardon). Analysis of this pathway is outside of the scope of this paper.

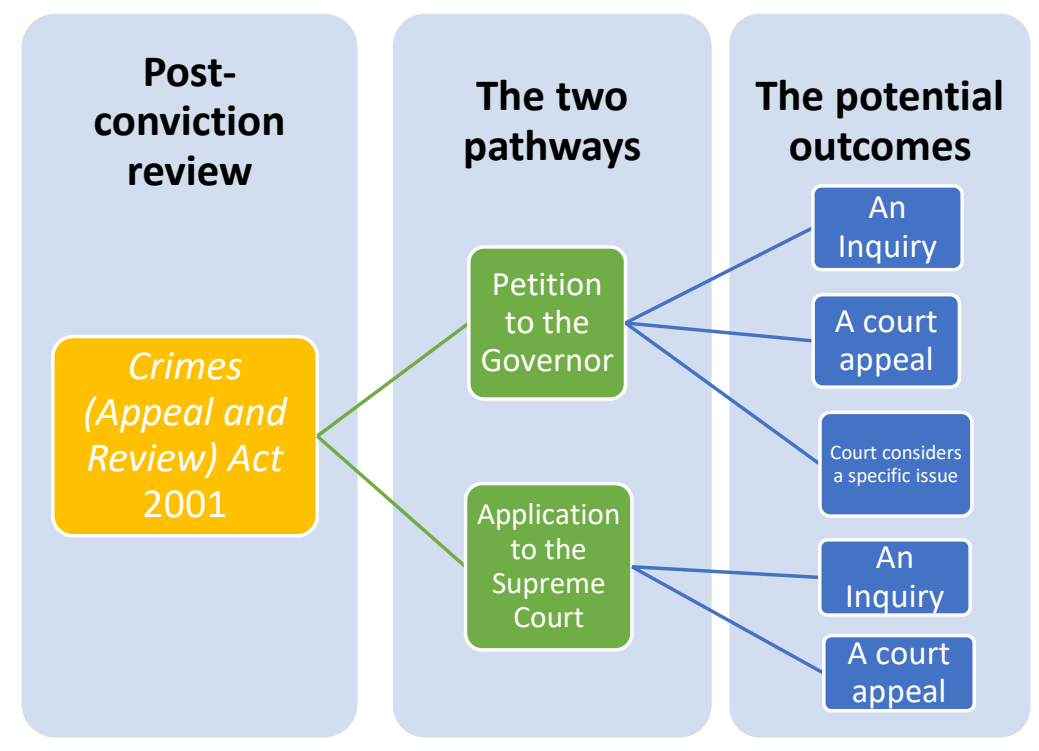

The relevant decision makers who determine if a case is sufficiently meritorious to receive a review, and subsequently if there is enough doubt to refer it to the Court of Criminal Appeal (after the review has been conducted), are the Governor, the Attorney General, and the Supreme Court (acting administratively).

The Governor is appointed by the Queen of England and not an elected official. ${ }^{19}$ She/he is the Crown representative and head of the executive branch of government in the State. The

conviction review, having ordered a Royal Commission into Criminal Justice in 1991. After a lengthy review of the criminal justice operations in the country, the establishment of a CCRC was recommended by the Commission Report, known as the "Runciman Report", online:

<https://assets.publishing.service.gov.uk/government/uploads/system/uploads/attachment data/file/27197 1/2263.pdf> [Runciman Report].

${ }^{17}$ Crimes (Appeal and Review) Act 2001 (NSW), No120, s 76 [Crimes Act]; It will be referred throughout this paper as "petition to the Governor". A petition to the Governor requesting that she/he exercise the pardoning power (Royal Prerogative of Mercy) is contained in the same section.

${ }^{18}$ Ibid at s 78.

${ }^{19}$ The Governor is the representative of the Queen in the State and the formal head of State, see Governor of New South Wales, Role of the Governor, online: <https://www.governor.nsw.gov.au/governor/role-ofthe-governor/>. She/he is not required to be legally trained and therefore advice from the Attorney General being the first law officer of the State is, by convention, usually provided. 
Attorney General is the first law officer of the State ${ }^{20}$ and is also an elected member of Parliament. ${ }^{21}$ She/he is appointed to the role of Attorney General by the Governor on the advice of the State Premier. ${ }^{22}$ The Supreme Court of New South Wales is the highest court in the independent State judiciary, but it can also exercise non-judicial functions. ${ }^{23}$

In practice, however, the Attorney General is effectively the decision maker in petitions to the Governor. The Attorney General also appears to have some oversight in applications to the Supreme Court, the outcome of which must be reported to her/him. ${ }^{24}$ This article is chiefly concerned with petitions to the Governor because of the author's experience of how this mechanism works in practice. ${ }^{25}$

\section{A. Petition to the Governor}

A petition to the Governor allows a convicted person (or someone on their behalf) to request a review of their conviction or sentence. ${ }^{26}$ There are several considerations in approving a petition: if fresh evidence is provided to substantiate the claim by the applicant (which came about post-conviction and after appeal(s)); and, if there has been a previous request for a review using

${ }^{20}$ Constitution Act 1902 (NSW) s 9A; see also Anne Twomey, The Constitution of New South Wales (Annandale, NSW, Australia: Federation Press, 2004) at 621-2 [Twomey].

${ }^{21}$ The Attorney-General fulfils a combination of legal, administrative, and political functions. In general terms, the responsibilities of the Attorney fall into four categories: (1) Legal representative of the Crown; (2) Legal adviser of the Government (including, where called upon, the Governor); (3) Administrator of the legal department; and (4) in certain special cases, adjudicator (select instances where the Attorney is required to act in a judicial capacity), see Twomey, supra note 20 at 691-3.

${ }^{22}$ The Attorney General is appointed by the Governor on advice from the Premier of the State. The Premier is the Chief Minister of the Government of the State. The Premier is tasked with leading and coordinating the work of the Ministers in Government, see NSW Government, The Premier, online:

<https://www.nsw.gov.au/premier-ofnsw/premier\#: :text=The\%20Premier\%20is\%20the\%20chief,Government\%20than\%20any \%20other\%20 Minister>. See also Twomey, supra note 20 at 690-1.

${ }^{23}$ It is well accepted that the independence of the judiciary is a fundamental principle of NSW constitutional law, see Twomey, supra at note 20. Note that judicial appointments in NSW are by the Governor on advice of the Executive Council. There is, however, very little known about how and why judges are appointed, see e.g., Elizabeth Handsley \& Andrew Lynch, "Facing up to Diversity? Transparency and the Reform of Commonwealth Judicial Appointments 2008-13" (2015) 37 Syd L Rev 187; Rebecca Ananian-Welsh \& Jonathan Crowe, Judicial Independence in Australia: Contemporary challenges, future directions (Annandale, NSW, Australia: Federation Press, 2016).

${ }^{24} \mathrm{~s} 79(5)$ of the Act.

${ }^{25} \mathrm{As}$ is demonstrated below, there are no extensive reports in the literature about how these review mechanisms work in practice. The conclusion that reform is required to NSW post-conviction review is not weakened by a disproportionate analysis of petitions to the Governor over applications to the Supreme Court. This is because the tenor of the issue with post-conviction review in NSW the way in which the system is structured does not promote independence, transparency, and accountability.

${ }^{26}$ Crimes Act, supra note 17 at s 76. 
this avenue. ${ }^{27}$ Approval of review can only occur if it "appears that there is doubt or question as to the convicted person's guilt, as to any mitigating circumstance in the case or as to any part of the evidence in the case." 28 If there is such a doubt or question, the Governor can order an inquiry; the Attorney General can send the matter to the Court of Criminal Appeal to be dealt with as a court appeal; or the Attorney General can ask the Court of Criminal Appeal to give an opinion on any point arising in the case. ${ }^{29}$ The Governor or Attorney General may refuse to consider or deal with a petition ${ }^{30}$ or defer consideration on certain grounds (e.g., if a court appeal avenue remains open to the applicant). ${ }^{31}$ A decision by the Governor to order an inquiry is to be informed by advice from the Attorney General; this is consistent with the convention that the Governor acts on advice of the relevant Minister in Executive Council. The author could not locate any instance in which a Governor has gone against the advice of the Attorney General in this context. The name of the review pathway being a petition to the Governor is, therefore, misleading given that the Attorney General is effectively the decision maker in all three options available to an applicant.

\section{B. An Application to the Supreme Court}

An application to the Supreme Court allows a convicted person (or someone on their behalf) to apply to the Supreme Court to request review of their conviction or sentence. ${ }^{32}$ The same considerations apply to granting a review (or not) as those for petitions to the Governor. A judge will examine the applicant's material and determine if there is doubt or question about the conviction or sentence. ${ }^{33}$ How the judge is selected for this task and what exact considerations are involved in the process of review are not defined. The Supreme Court can order an inquiry or it can be dealt with by way of appeal in the Court of Criminal Appeal. ${ }^{34}$ Proceedings under this section are not judicial proceedings despite the decision maker being the Supreme Court. ${ }^{35}$ The

${ }^{27}$ Ibid at $\mathrm{s} 77$.

${ }^{28} \mathrm{Ibid}$ at s 77(2).

${ }^{29} \mathrm{Ibid}$ at ss 77(1)(a); 77(1)(b); and 77(1)(c), respectively.

${ }^{30} \mathrm{Ibid}$ at s $77(3)$.

${ }^{31}$ Ibid at s 77(3A).

${ }^{32}$ Ibid at s 78.

${ }^{33}$ Ibid at s 79(2). The Attorney-General and Minister for Prevention of Domestic and Sexual Violence is the Minister currently responsible for the administration of the Act; see Allocation of the Administration of Acts (NSW) [as of 6 October 2021].

${ }^{34}$ The only difference is that the Supreme Court cannot request the Court of Criminal Appeal to provide an opinion on any part of the case, see s 79(1) of the Act.

${ }^{35}$ In determining an application under s 78 of the Act, the Supreme Court performs an administrative function that does not amount to a judicial proceeding, see 79(4) of the Act; Varley v Attorney-General (NSW) (1987), 8 NSWLR 30 at 48-50 (Hope JA); Eastman v DPP (ACT) (2003), 214 CLR 318. Such decisions are therefore amenable to review for jurisdictional error, see Patsalis v Attorney-General (NSW), [2013] NSWCA 343 at [23] - [24] (Basten JA). The conferral of administrative functions on a judicial body raises concerns about the separation of powers and the preservation of an independent and impartial judiciary. Although there is no strict separation of powers (as a matter of law) in the Australian States (see e.g., Clyne v East, [1967] 2 NSWR 483; Kable v Director of Public Prosecutions (NSW) (1996), 189 CLR 
Attorney General also appears to have to have oversight of this pathway: the legislation states that a copy of the application must be sent to the Attorney General. ${ }^{36}$ The extent of that involvement is unclear and there is no literature commenting on this point.

\section{An Inquiry as an Outcome Arising from a Petition to the Governor and an Application to the Supreme Court}

An inquiry can arise from both review avenues. It is a special hearing convened to investigate an issue(s). It is an inquisitorial process ${ }^{37}$ which is distinct from the adversarial approach to criminal litigation which is typically conducted in NSW. ${ }^{38}$ A Commissioner, usually a former judicial officer, is appointed to carry out the inquiry. ${ }^{39}$ She/he is appointed by either the Governor or the Supreme Court, depending on who ordered the inquiry. To assist the inquiry, a legal practitioner (usually a senior barrister) is appointed as Counsel Assisting the Commissioner. Terms of reference for the inquiry are set by either the Governor or Supreme Court in a formal order given once a decision is made; these outline the matters to be investigated. ${ }^{40}$

The Commissioner has wide powers to conduct the investigation; they are the extraordinary powers afforded to Commissioners of Royal Commissions. ${ }^{41}$ What evidence is heard and formally admitted to the proceedings is a decision for the Commissioner with the assistance of Counsel

51), the Commonwealth Constitution (by implication) prohibits State Parliaments from conferring on State courts and judges functions that impair the institutional integrity of the State courts, see e.g., Wainohu v New South Wales (2011), 278 ALR 1; Vella v New South Wales, [2019] HCA 38. This has the effect of preserving the independence and impartiality of those courts and judicial officers, with a view to maintaining public confidence in the judiciary. The application of those principles raises difficult questions in many contexts. For diverging views on whether post-conviction review mechanisms breach the separation of powers, see e.g., David Caruso \& Nicholas Crawford, "The Executive Institution of Mercy in Australia: The Case and Model for Reform" (2014) 37:1 UNSW LJ 312; Cf, Catherine Dale Greentree, "Retaining the Royal Prerogative of Mercy in New South Wales" (2019) 42:4 UNSW LJ 1328.

${ }^{36}$ Crimes Act, supra note 17 at s 78(2).

${ }^{37}$ See generally, Leonard Arthur Hallett, Royal Commissions and Boards of Inquiry: Some legal and procedural aspects (Pyrmont, Australia: Law Book Co of Australasia, 1982); Stewart Field, "Fair Trials and Procedure Tradition in Europe" (2009) 29:2 Oxford J Leg Stud 365.

${ }^{38}$ See e.g., Australian Law Reform Commission, Review of the Adversarial System of Litigation (Report No 89, December 1999) at 102; Kent Roach, "Wrongful Convictions: Adversarial and Inquisitorial Themes" (2010) 35:2 NCJ Int'l L \& Com Reg 388 at 391.

${ }^{39}$ See generally, Gabrielle Appleby \& Alysia Blackham, "The Growing Imperative to Reform Ethical Regulation of Former Judges" (2018) 67:3 Int'l \& Comp LQ 505.

${ }^{40}$ Nowhere in the Royal Commission Act 1923 (NSW) could the author locate a power given to a Commissioner of an inquiry to either widen or restrict the scope of the inquiry once it is ordered by the Governor or the Supreme Court.

${ }^{41}$ All the powers of the Royal Commission Act 1923 (NSW) (except section 17). A Royal Commission is a public inquiry and is "the highest form of inquiry on matters of public importance", see Royal Commissions, online: <https://www.royalcommission.gov.au/about-royal-commissions > . 
Assisting. ${ }^{42}$ After inquiry hearings have closed, the Commissioner is required to prepare a report to send (along with the transcripts of the depositions from the hearings) to the Governor or Chief Justice of the Supreme Court. ${ }^{43}$ The Commissioner can also refer the case to the Court of Criminal Appeal if she/he considers that there is reasonable doubt about the conviction or some issue with an applicant's sentence. ${ }^{44}$ For both pathways, the final decision to be made after the inquiry has concluded - referral of the case to the Court of Criminal Appeal for consideration of whether the convictions should be quashed or sentence to be reviewed, or to take no action at all - is ultimately the remit of the Governor. ${ }^{45}$ It is clear from the legislation that the Governor theoretically has the final word; but by convention, that decision would typically be informed through formal advice of the Attorney General. ${ }^{46}$ As stated, there is no documented instance which the author could locate in which a Governor has gone against the advice of an Attorney General in the context of postconviction review. This makes the Attorney General, in effect, the relevant decision maker.

As outlined above, post-conviction review in NSW is dominated by a small number of high-level executive actors whose process for reviewing cases is often shrouded in secrecy. A major concern is the need for decisions to be fair and considered properly by those in power. Below is summary of what justice and fairness mean in the context of post-conviction review.

\section{Justice as Fairness: Independence, Transparency and Accountability}

For centuries, defining justice (as it relates to the law) has been fraught with difficulty. ${ }^{47}$ It has preoccupied the work of some of history's best known philosophers - Aristotle, ${ }^{48}$ Aquinas, ${ }^{49}$

\footnotetext{
${ }^{42}$ The author could not locate any legislation or case law which states that the only party permitted to tender documents for admission into evidence is Counsel Assisting the inquiry. However, public commentary has said that the function of Counsel Assisting is the organisation and administration of a Royal Commission or inquiry, see Peter M Hall, "The role of counsel assisting in commissions of inquiry" (2005), online: Bar News <http://www.austlii.edu.au/au/journals/NSWBarAssocNews/2005/14.pdf > at 31 [Hall].

${ }^{43}$ Crimes Act, supra note 17 at ss 82(1)(a) and 82(1)(b), respectively.

${ }^{44}$ Ibid at s 82(2)(a).

45 "The Governor may then dispose of the matter in such a manner as to the Governor appears just", Ibid at s 82(4).

${ }^{46}$ As a matter of convention, the Governor acts on the advice of the Executive Council in exercising powers conferred on her/him by statute, see Twomey, supra note 20 at 635; see also Interpretation Act 1987 (NSW) s 14 which is discussed in David Caruso \& Nicholas Crawford, "The Executive Institution of Mercy in Australia: The Case and Model for Reform" (2014) 37:1 UNSW LJ 312 at 314-6.

${ }^{47}$ See, e.g., Denise Meyerson, Jurisprudence (Oxford: Oxford University Press, 2011) at 4-7.

${ }^{48}$ See, e.g., Aristotle, Nicomachean Ethics $1^{\text {st }}$ ed (London: Penguin Classics, 2003); Aristotle, The Politics (London: Penguin Classics, 1981).

${ }^{49}$ See, e.g., Anthony J Lisska, Aquinas's Theory of Natural Law: An Analytic Reconstruction (Oxford: Oxford University Press, 1998); Eleonore Stump, Aquinas (London: Routledge, 2003).
} 
and Hume. ${ }^{50}$ A common thread in philosophical thought is a recognition that the law provides rights and obligations for society to function in an organised and civilised way. ${ }^{51}$ Some philosophers differ, however, on the extent to which morality is (and should be) reflected through the law. ${ }^{52}$

Innate understandings of right and wrong are embodied in the concept of natural law: those understandings are derived from humanity (and thus morality) ${ }^{53}$ Immanuel Kant, one of the first proponents of natural law, argued that ethical principles are justified by reason alone and are hence indefeasible by law. ${ }^{54}$ According to Kant, ethical principles are, therefore, inherent; although they are not created by law, they should be reflected in law. ${ }^{55}$ Another approach is the utilitarian theory of justice which is derived from the early work of Jeremy Bentham, and later, John Stuart Mill. ${ }^{56}$ Justice is concerned with utility, guided by the aim of achieving the greatest happiness for the greatest number of people. ${ }^{57}$ This shifted the focus away from individual rights and freedoms to the collective experience. In the context of post-conviction review, a utilitarian might not place as much weight on the implications of wrongful convictions given they happen so infrequently (and they do not have an impact on the majority). This, however, would stand in stark contrast to natural law and liberal theories in which individual rights and freedoms are core values.

In response to utilitarian conceptions of justice, eminent philosopher John Rawls proposed a new theory: justice as fairness. ${ }^{58}$ In doing so, he relied on distributive justice and revived the

${ }^{50}$ See, e.g., Donald C Ainslie \& Annemarie Butler, The Cambridge Companion to Hume's Treatise (Cambridge: Cambridge University Press, 2015).

${ }^{51}$ John Finnis, "Natural Law Theories" (2020) (Summer) SEP, online:

$<$ https://plato.stanford.edu/entries/natural-law-theories/>.

${ }^{52}$ See, e.g., Michael Sandel, Justice: What's The Right Thing To Do? (New York: Farrar, Straus \& Giroux, 2010). For a critique on some of the major theories of justice, see generally, Amartya Sen, The Idea of Justice (New Delhi: Allen Lane, 2009).

${ }^{53}$ See, e.g., Marcus Tullius Cicero, The Political Works of Marcus Tullius Cicero (Toledo, OH: Veritatis Splendor Publications, 2014); Aristotle, The Politics (London: Penguin Classics, 1981); Plato, Gorgias, ed, E R Dodds, $2^{\text {nd }}$ ed (Oxford: Oxford U Press, 1990), Plato, Republic, 2nd ed (Indianapolis, IN: Hackett Classics, $2^{\text {nd }}$ ed, 1992); Lon Fuller, The Morality of Law, revised ed (New Haven: Yale University Press, 1965); Thomas Aquinas, Summa Question 94, A.3; John Finnis, Natural Law and Natural Rights, 2nd ed (Oxford: Oxford University Press, 2011).

${ }^{54}$ Immanuel Kant, The Doctrine of Virtue: Part II of the Metaphysic of Morals, trans. Mary J Gregor (New York: Harper Torchbooks, 1964).

${ }^{55}$ Ibid; Robert Johnson \& Adam Cureton, "Kant's Moral Philosophy” (2021) (Spring) SEP, online: https://plato.stanford.edu/entries/kant-moral/.

${ }^{56}$ Jeremy Bentham, An Introduction to the Principles of Morals and Legislation (Oxford: Oxford University Press, 1823); John Stuart Mill, Utilitarianism (North Charleston: Createspace Independent Publishing Platform, 1879); John Stuart Mill, "Utilitarianism” in Roger Crisp, ed, Utilitarianism (Oxford: Oxford University Press, 1998) at 56.

${ }^{57}$ Ibid.

${ }^{58}$ John Rawls, Justice as Fairness: A Restatement (London: Belknap Press, 2001) [Rawls]. See also his earlier works: John Rawls, A Theory of Justice (London: Belknap Press, 1999); John Rawls, "Justice as 
concept of the social contract. ${ }^{59}$ Rawls opined that justice could be achieved through a reset of society's moral and ethical principles. This, however, could only be achieved when all members of society, in a hypothetical state, are unknowing of their individual features and characteristics, in what he described as the "original position." $60 \mathrm{He}$ argued that two principles arise from the original position: the first is that all people are entitled to equal basic liberties which are indefeasible; and the second is that social and economic opportunities should be afforded to everyone on an equal basis. According to Rawls, if opportunities cannot achieve pure equality, they should advantage the worst off in society. ${ }^{61}$ This, in contrast to utilitarianism, would see wrongful convictions as a prime example of an unacceptable failure of society. Rawls' theory is apt as a framework to evaluate post-conviction review in this article because it is concerned with procedural "justice" as opposed to substantive law, which is the chief focus of this analysis. ${ }^{62}$ Importantly, Rawls' theory raises the important issue around power given to decision makers in "how [they] may reach a decision and what they may authorise."63

This article identifies independence, transparency, and accountability as three essential features of post-conviction review and will address each in turn below. ${ }^{64}$

\section{A. Independence}

Much of the domestic and international literature on post-conviction review refers to the need for "independent review mechanisms." ${ }^{65}$ Independence in this context refers to a decision

Fairness: Political not Metaphysical" (1985) 14 Philos Public Aff 223; John Rawls, Political Liberalism (New York: Columbia University Press, 2005); John Rawls, “The Law of Peoples" (1993) 20:1 Crit Inq 36.

${ }^{59}$ Rawls, supra at note 58.

${ }^{60}$ The "original position" refers to a situation where an individual imagines themselves behind a "veil of ignorance", such that all personal characteristics are forgotten including natural abilities and position in society. Rawls argues that such a state allows individuals to think as equal, free, rational and moral beings. This allows society to re imagine agreed moral and ethical principles by which to live, see Rawls, ibid at note 58 .

${ }^{61}$ Ben Davies, "John Rawls and The "Veil of Ignorance"”, online: <https://human.libretexts.org/Bookshelves/Philosophy/Introduction_to_Ethics_(Levin_et_al.)/03\%3A_Pe rsons Autonomy the Environment and Rights/3.02\%3A John Rawls and the Veil of Ignorance (Be n_Davies)>.

${ }^{62} \mathrm{He}$ considers the rule of law as one which is characterised by "formal justice" and "regularity": Rawls, supra note 58 at 236. See also Donald HJ Hermann, "The Fallacy of Legal Procedure as Predominant over Substantive Justice: A Critique of the Rule of Law in John Rawls' a Theory of Justice" (1974) 23:4 DePaul L Rev 1408 at 1409 [Hermann].

${ }^{63}$ J R Lucas, The Principles of Politics (Oxford: Oxford University Press, 1966) 107 cited in Hermann, supra note 62 at 1414.

${ }^{64}$ Magnus Ulvang, "Criminal and Procedural Fairness: Some Challenges to the Presumption of Innocence" (2014) 8 Crim Law Philos 469 at 472.

${ }^{65}$ See generally, P Braiden \& J Brockman, "Remedying Wrongful Convictions Through Applications to the Minister of Justice Under Section 690 of the Criminal Code" (1999) 17 WYAJ 5. The Marshall 
maker being free from either real or perceived conflicts of interest. ${ }^{66}$ It is an essential feature of decision making in the law, especially in the criminal law. For example, there has always been significant focus on having an independent judiciary in Australia. That is chiefly because there is a need for impartial adjudication of issues necessitated by the rule of law. The former Chief Justice of the High Court of Australia, Gerard Brennan said, "[i]f that independence were, or were thought by the litigants or the public to be, put at risk, the rule of law would be imperilled and the peace and order of society would be problematic." ${ }^{\prime 67}$ Judges, therefore, need to be independent and to be seen to be independent. While post-conviction review is in the hands of executive government actors in NSW, they are in substance still adjudicating on issues which affects people's rights and their liberty. For this reason, the need for independence is of the same importance as it is in the judiciary.

The role of the Attorney General is said to be potentially "conflicting" given the different roles and responsibilities she/he has. ${ }^{68}$ One example of that conflict in the context of postconviction review is the extent of the relationship between the Attorney General and Office of the Director of Public Prosecutions (ODPP). The management role the Attorney General has over the ODPP could create a potential conflict situation where mistakes are made by the ODPP or police which have either caused or exacerbated a wrongful conviction. It becomes problematic when the Attorney General is tasked with deciding if a case should get a review. ${ }^{69}$ Simply put, it does not bode well that there is a connection between the agency that pursued the charges and the decision

Commission in Canada found that "the type of investigative capability required for an effective review process was one independent of official governmental control and perceived to be so by the public", see Peter H Howden, "Judging Errors of Judgment: Accountability, Independence \& (and) Vulnerability in a Post-Appellate Conviction Review Process" (2002) 21 WYAJ 569 at 587 [Howden]; for criticism of independence and transparency in the Canadian context, see Paul J Saguil, "Improving Wrongful Conviction Review: Lessons from a Comparative Analysis of Continental Criminal Procedure" (2007) 45:1 ALR 117.

${ }^{66}$ For example, the Attorney General of NSW is responsible for giving advice to the Governor on petitions for review. Because the Attorney General is an elected official, it could be said they he/she could be "subject to majoritarian electoral considerations and cabinet solidarity", Howden, supra note 65 at 587.

${ }^{67}$ Gerard Brennan, "Judicial Independence” (2 November 1996), online:

<https://www.hcourt.gov.au/assets/publications/speeches/former-justices/brennanj/brennanj_ajc.htm>.

${ }^{68}$ The Attorney General effectively occupies two offices: a common law office being the first law officer of the State and a ministerial office with a portfolio given to them. By virtue of this, it is argued that there can be conflicting responsibilities because of the dual positions, see Gerard Carney, "Comment - The Role of the Attorney-General" (1997) 9(1) Bond L Rev 1 at 2. See also Anne Twomey, The Veiled Sceptre: Reserve Powers of Heads of State in Westminster Systems (Cambridge: Cambridge University Press, 2018) at 55-7 where mention is given to the inherent conflict of interest that an Attorney may face in advising the Governor, and the potential for unconscious bias.

${ }^{69}$ For more functions of the Attorney General in relation to the ODPP, see Director of Public Prosecutions Act 1986 (NSW) ("DPP Act”) Part 4 "The Attorney General". 
maker who is tasked with potentially challenging it. ${ }^{70}$ Even without real conflict, the perception of such is enough to call into question the independence of the Attorney General in having responsibility for post-conviction review in NSW.

\section{B. Transparency}

Transparency, a cornerstone of the principle of "open justice", is a key feature of any process in the criminal law. ${ }^{71}$ This is reflected in the most standard of legal processes - for example, open court proceedings and the publishing of judgments. ${ }^{72}$ It has long been recognised that transparency is essential for justice not only to be done, but also seen to be done. ${ }^{73}$ This is critically important to the maintenance of public confidence in the legal system and informed public participation in the law. Having clear laws and publicly available procedures to guide decision makers is fundamental to ensuring that cases are treated with consistency and the public are aware of how, and on what basis, cases are being decided. Public participation (and thus scrutiny) of governmental decisions is also a hallmark feature of a democratic society. ${ }^{74}$ Because very little is known about what happens after an application for review is submitted to either the Governor or the Supreme Court, ${ }^{75}$ there is limited transparency overall in the post-conviction review system in NSW. This is examined in more depth below both generally and in Ms. Folbigg's case.

\section{Accountability}

Accountability is another critical element necessary in all legal processes, particularly those which involve a person's liberty. Supplying executive actors (the Governor, Attorney General and judges acting administratively) with the enormous power to decide if a person should remain convicted must be accompanied by responsibility for those decisions. ${ }^{76}$ Meaningful accountability in this context encompasses trust and confidence that the "right" thing will be done

\footnotetext{
${ }^{70}$ In Canada, where post-conviction review is currently conducted almost identically to NSW, a lack of independence is seen as one of the biggest barriers to remedying miscarriages of justice, see e.g., Howden, supra at note 65. Cf Scullion who claims that criticism levelled at independence may be spurious: Kerry Scullion, "Wrongful Convictions and the Criminal Conviction Review Process pursuant to Section 696.1 of the Criminal Code of Canada" (2004) 46:2 Can J Crim Just 189 [Scullion].

${ }^{71}$ This is yet another key feature that is lacking in Canadian post-conviction review, which has been subject to scrutiny by scholars and advocates, see e.g., Howden, supra at note 65. Cf Scullion states that the level of transparency has been enhanced in recent times, Scullion, supra at note 70.

72 James Spigelman, "Seen to be Done: The Principle of Open Justice - Part I" (2000) 74 Aust L J 290.

${ }^{73}$ See e.g., Beverley McLachlin, "Courts, Transparency and Public Confidence - To the Better Administration of Justice" (2003) 8:1 Deakin L Rev 1 [McLachlin]; Claire Baylis, "Justice Done and Justice Seen to be Done - The Public Administration of Justice" (1991) 21 Vic Univ Wellingt L Rev 177. ${ }^{74}$ Emma Cunliffe, "Open Justice: Concepts and Judicial Approaches” (2012) 40 FLR 386 at 389.

${ }^{75}$ Crimes Act, supra note 17 at ss 76 and 78, respectively.

${ }^{76}$ Howden, supra at note 65; Peter Newell, "Taking Accountability into Account: The Debate so Far" in Peter Newell \& Joanna Wheeler, eds, Rights, Resources and the Politics of Accountability (London: Zed Books, 2006) at 37-59.
} 
by those in power. ${ }^{77}$ Accountability intersects importantly with transparency, as both are required for public confidence in the administration of justice. ${ }^{78}$ The fact that very little is known about what occurs behind the scenes of post-conviction review makes it difficult to assign appropriate accountability to decisions.

Independence, transparency, and accountability are three necessary features of postconviction review. Because there is often heightened public interest in cases which are significant wrongful convictions, they frequently attract political attention. This tends to be the case if convictions are considered reprehensible, such as the murder of infant children as in the cases of Lindy Chamberlain and Kathleen Folbigg. Because of the nature of what post-conviction review is aimed to achieve, and invariably the subject matter being serious criminal convictions, there is a need for high levels of independence, transparency, and accountability in post-conviction review. This is necessary to ensure that all members of the public have faith that cases are dealt with fairly and according to proper process, whatever the ultimate outcome. This article now turns to outline some criticisms of post-conviction review processes in NSW.

\section{Some key criticisms of post-conviction review in NSW}

The aim of post-conviction review is the identification and correction of wrongful convictions. In NSW at present, there are significant barriers to a convicted person's ability to access review; one prominent obstacle is a lack of guidance on how to formulate a review application. The NSW Justice Government Department advises that independent legal advice should be sought before making an application for review. ${ }^{79}$ This is concerning given the simple fact that convicted people are unlikely to be able to locate a lawyer when they are incarcerated, let alone having the financial resources to fund legal assistance. Persons serving a lengthy sentence for serious crime(s), might also not possess the knowledge or resources to engage the assistance of pro bono lawyers or community legal assistance. In the likely event that they are left without legal assistance, the preparation of a cogent application is nearly impossible. The absence of a prescribed form or any suggestions for preparation of the application for the Governor or the Supreme Court $^{80}$ is a major barrier of access to justice. ${ }^{81}$

${ }^{77}$ Richard Mulgan \& John Uhr, "Accountability and governance” in Glyn Davis \& Patrick Weller, eds, Are You Being Served? State, Citizens and Governance (St Leonards, NSW, Australia: Allen \& Unwin, 2001) 152 at 170.

${ }^{78}$ McLachlin, supra at note 73.

${ }^{79}$ NSW Government Justice, Review of convictions or sentences under the Crimes (Appeal and Review) Act 2001 Factsheet, online:

<https://www.justice.nsw.gov.au/Documents/Contact\%20us/Freq\%20Ask\%20Ques/review-ofconvictions-or-sentences.pdf $>$.

${ }^{80} \mathrm{Ibid}$.

${ }^{81}$ There are other factors which make accessing the legal system more difficult for some convicted people, for example, mental health issues and language barriers; consideration of those factors are outside of the scope of this paper. 
A lack of independence on the part of decision makers in post-conviction review is best highlighted through the relationship the Attorney General has with the State prosecution agency. In NSW, the Attorney General ${ }^{82}$ is the responsible Minister for the ODPP, the agency in charge of criminal proceedings on behalf of the State. According to the legislation, the Director of the ODPP is answerable to the Attorney General for "due exercise of the Director's functions." 83 The Director, upon request, shall consult with the Attorney General on matters in which the Director can exercise her/his discretion. ${ }^{84}$ The Attorney General also has the same functions as the Director in relation to, inter alia, finding a bill of indictment in respect of an indictable offence or directing the discontinuation of proceedings. ${ }^{85}$ The Attorney General's power prevails in the event of a conflict with the Director's actions in a matter. ${ }^{86}$ Once again, this is problematic in situations in which the Attorney General must decide if a review is warranted and such a consideration involves, for example, errors made by the ODPP.

Another challenge facing post-conviction review in NSW is a lack of knowledge about what occurs behind the scenes. Post-conviction review is rarely discussed in Australian public life. This might be because it represents a relatively small issue in criminal justice overall, ${ }^{87}$ and cases which obtain a review are rare. There is also limited scholarship, and certainly no in-depth critical analysis of the NSW system that provides insights from practice. The principle of open justice necessitates transparency and accountability in all decisions involving criminal law. In the context of post-conviction review, publicly available procedures and/or guidelines for how the Governor, Attorney General and judges make decisions are important for transparency and accountability. ${ }^{88}$ Currently, there are none. This raises some important questions:

1) Who is reviewing the application?

2) What timeframe is to be expected for review?

3) Is there consistency in review of similar cases?

4) When issues arise around forensic evidence, for example, what approaches are taken for engagement of expert advice/evidence?

These are significant questions which are currently unanswered.

${ }^{82}$ See DPP Act "Status Information".

${ }^{83}$ DPP Act s 4(3); It is, however, unknown the extent of the interaction between the Director and the Attorney General, and whether, in fact the Attorney General has very little, or a substantial influence, over the operations of the ODPP.

${ }^{84}$ DPP Act s 25(1).

${ }^{85}$ Ibid at $\mathrm{s} 7(2)$.

${ }^{86} \mathrm{Ibid}$ at s $28(1)$.

${ }^{87}$ Quantifying wrongful convictions is a difficult task, and therefore statistics on the frequency of such cases are likely significantly under reported, see Tony G Poveda, "Estimating Wrongful Convictions" (2001) 18:3 Justice Q 689 at 705; see generally, Kelly Walsh et al, "Estimating the Prevalence of Wrongful Convictions" (2017) Office of Justice Programs, online: <https://www.ojp.gov/pdffiles1/nij/grants/251115.pdf>.

88 John McKechnie, "Directors of Public Prosecutions: Independent and Accountable" (1996) 26 Univ West Aust Law Rev 266. 
A lack of publicly available guidelines/procedures has in the past been labelled as "secretive" in relation to prosecution agencies. ${ }^{89}$ Given that both prosecution agencies and the Attorney General have significant powers in relation to determining a person's liberty, the same standard of transparency should be applied to both. The impacts of a lack of guidelines can manifest in different ways. Without some guidance on how to approach matters, this leaves it almost entirely up to the discretion of the decision maker. Wide discretion is known to sometimes lead to abuse and "can dangerously be synonymous with unchecked power." ${ }^{90}$ Defined, clear, and accessible processes also allow for greater acceptance of unfavourable outcomes because the public is informed about how the decision is made. ${ }^{91}$ It is thus problematic that NSW has no publicly available procedures and guidelines. It makes this area of the legal system inaccessible to the public and incapable of accurate scrutiny.

The UK's previous approach to post-conviction review (which was very similar to that in NSW) had been described as a "pathetic little organisation"92 and one in which "[i]ts processes were opaque and unaccountable. Officials mostly saw their job as rebutting evidence uncovered by prisoners, lawyers, journalists, and campaigners. Cases dragged on for years frequently culminating in curt, inexplicable dismissals." 93 As the below case study of Kathleen Folbigg will reveal, there is some truth in this description of the NSW process.

\section{The Folbigg Case}

Kathleen Folbigg's case has been recognised as potentially the biggest miscarriage of justice in Australian history. ${ }^{94}$ She has previously been labelled Australia's "worst female serial killer" and the most "hated woman in Australia." She is now in her $19^{\text {th }}$ year of prison, for which she has served the entire duration in maximum security prisons in NSW. After almost two decades, a significant number of leading scientists and doctors, and many members of the media, have raised

${ }^{89}$ Australian Law Reform Commission, Sentencing of Federal Offenders (Report No 15, 1980). See also Kenny Yang, "Public Accountability of Public Prosecutions" (2013) 20:3 Murdoch Univ L Rev 28 at 37.

${ }^{90}$ Michael A Simons, "Prosecutorial Discretion and Prosecution Guidelines: A Case Study in Controlling Federalization" (2002) 75 NYU L Rev 893 at 899.

${ }^{91}$ James L Gibson, "Understandings of Justice: Institutional Legitimacy, Procedural Justice, and Political Tolerance" (1989) 23(2) Law Soc Rev 469 at 471.

${ }^{92}$ A quote from Michael Zander QC cited in Hoyle \& Sato, supra note 10 at 4 . See generally Hoyle \& Sato for an account of how the Home Secretary organisation, the Criminal Cases Unit "C3", conducted review prior to the establishment of the CCRC.

${ }^{93}$ Paul May, "Partly excellent, partly abysmal': 20 years of the CCRC" The Justice Gap (31 March 2017), online: < https://www.thejusticegap.com/partly-excellent-partly-abysmal-20-years-ccrc/>.

${ }^{94}$ Robyn Tongol "Is Kathleen Folbigg Innocent? New Evidence Suggests She Is," Lawyers Weekly (17

September 2021), online: <https://www.lawyersweekly.com.au/podcast/32524-is-kathleen-folbigg-

innocent-new-evidence-suggests-she-is>; Naomi Neilson, "Every Lawyer Should Be Concerned:

Kathleen Folbigg, Miscarriages of Justice and the Opportunities to Reform the Justice System," Lawyers Weekly (21 September 2021), online:

<https://www.lawyersweekly.com.au/biglaw/32557-every-lawyer-should-be-concerned-kathleen-folbiggmiscarriages-of-justice-and-the-opportunities-to-reform-the-justice-system> . 
the prospect that Ms. Folbigg might be innocent. ${ }^{95}$ Eminent, world recognised child and public health researcher Professor Fiona Stanley said in relation to Ms. Folbigg's case that "[i]t is deeply concerning that medical and scientific evidence has been ignored in preference of circumstantial evidence..." ${ }^{96}$ Professor John Shine, President of the Australian Academy of Science has supported the call for Ms. Folbigg's release saying, "it is the right thing to do" based on the existence of natural causes of death for the children. ${ }^{97}$

Below is a brief timeline of the legal proceedings Ms. Folbigg has had to date; ${ }^{98}$ these will be explained in more detail below.

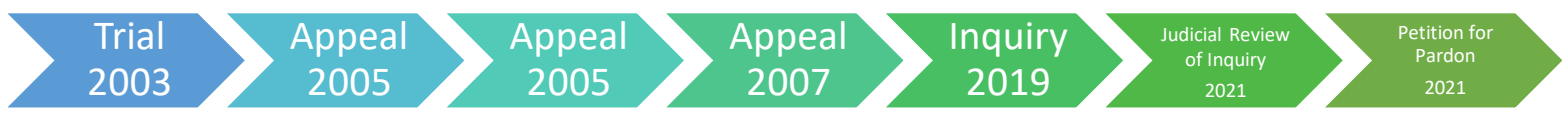

On 1 February 1989 Caleb Folbigg was born, and at only 19 days old he died. His death certificate recorded the death as Sudden Infant Death Syndrome ("SIDS") with a finding of laryngomalacia. ${ }^{99}$ The next child, Patrick Folbigg was born on 3 June 1990. At around four months of age, Patrick suffered an Apparent Life-Threatening Event ("ALTE") followed by blindness and intractable seizures that continued for four months. He died on 13 February 1991 and his death was recorded as epilepsy due to an encephalopathic disorder. ${ }^{100}$ Ms. Folbigg's next child, Sarah Folbigg, was born on 14 October 1992. At 10 months old, four days after seeing her general

${ }^{95}$ For an overview on the new science in this case, see the 60 Minutes program entitled 'Murder Under the Microscope' which aired in August 2021, online: <https://www.youtube.com/watch?v=V00rgtcfKJ8>. 60 Minutes also aired a program in March 2019 which questioned the safety of Ms. Folbigg's convictions entitled 'Mothers accused of killing their four babies', online:

〈https://www.youtube.com/watch?v=4z4YtquTJjM>.

${ }^{96}$ Australian Academy of Science, Leading Scientists Call for Folbigg Pardon, online:

$<$ https://www.science.org.au/news-and-events/news-and-media-releases/leading-scientists-call-folbiggpardon>.

${ }^{97}$ Ibid.

${ }^{98}$ Outlined in the diagram are the substantive appeals Ms Folbigg had after her conviction and sentence. She also appealed in 2002 to the Supreme Court of NSW prior to her trial commencing, appealing the decision of a single judge to refuse to have her charges tried separately: $R v$ Folbigg, [2002] NSWSC 1127. Ms Folbigg appealed this decision to the Court of Criminal Appeal in 2003, which was denied: $R v$ Folbigg, [2003] NSWCCA 17. Ms Folbigg then applied for special leave of the High Court of Australia, appealing the previous decision of the Court of Criminal Appeal refusing her application for separate trials: Folbigg $v$ The Queen, [2003] HCA Trans 589.

${ }^{99}$ For full details, see Inquiry into the Convictions of Kathleen Megan Folbigg, Forensic Pathology Tender Bundle (Exhibit H), online:

<https://www.folbigginquiry.justice.nsw.gov.au/Documents/Exhibit\%20H\%20\%20Forensic\%20Pathology\%20Tender\%20Bundle.pdf> at 3-11, 24-9 [Pathology Tender].

${ }^{100} \mathrm{Ibid}$ at $36-7$. 
practitioner for a croupy cough and being started on antibiotics, she died. The death certificate recorded the cause of death as SIDS. ${ }^{101}$ The last child, Laura Folbigg, was born on 7 August 1997. At 18 months old, two days after being treated with paracetamol and pseudoephedrine for a respiratory infection, she died. Her death was recorded as "undetermined" with an incidental finding of myocarditis. ${ }^{102}$

In 2003, Ms. Folbigg was convicted of: the manslaughter of Caleb; maliciously inflicting grievous bodily harm upon Patrick; the murder of Patrick, Sarah and Laura. She was sentenced to 40 years imprisonment with a non-parole period of 30 years. ${ }^{103}$ This was later reduced on appeal to 30 years imprisonment with a 25 -year non-parole period. ${ }^{104}$

The prosecution case theory was that Ms. Folbigg smothered each of her children in a state of rage/stress. There was, however, no pathological evidence from the autopsies that she smothered any of her children. On the contrary, each child had natural causes of death diagnosed. In the absence of pathological evidence to support the prosecution's case theory, it proceeded on two main points: (1) "Meadow's Law", from which it was derived that multiple infant deaths in one family from natural causes are so rare it was impossible to happen in the Folbigg family; (2) Ms. Folbigg's diaries were to be construed as confessions that she murdered her children. ${ }^{105}$

The five separate charges against Ms. Folbigg were joined together and the prosecution case relied heavily on tendency and coincidence evidence. ${ }^{106}$ The prosecution contended that the

\footnotetext{
${ }^{101}$ Ibid at 90-102.
}

${ }^{102}$ Ibid at $166-77$. The forensic pathologist, Dr. Allan Cala, who conducted the autopsy indicated at the Inquiry into Ms. Folbigg's convictions in 2019 "I think, with Laura, there's undoubtedly myocarditis and I've said I can't exclude that as being the cause of death" see Inquiry into the Convictions of Kathleen Megan Folbigg, Transcript 21 March 2019, online:

<https://www.folbigginquiry.justice.nsw.gov.au/Documents/FINAL\%20\%20Transcript\%20of\%2021\%20March\%202019.pdf> at 281 line 20 [Transcript 21 March].

${ }^{103} R$ v Folbigg, [2003] NSWSC 895.

${ }^{104} R v$ Folbigg, [2005] NSWCCA 23.

105 There was other evidence heard at the trial that formed the prosecution's circumstantial case, including that of Ms. Folbigg's former husband, Craig Folbigg. However, the central focus was on the aspects mentioned above. For the full trial transcripts, see Inquiry into the Convictions of Kathleen Megan Folbigg, Complete set of transcripts of evidence given at 2003 trial (Amended Exhibit F), online:

<https://www.folbigginquiry.justice.nsw.gov.au/Documents/Amended\%20Exhibit\%20F.pdf>

[Trial Transcripts].

${ }^{106}$ For a brief account, see Report of the Inquiry into the Convictions of Kathleen Megan Folbigg, online: <https://www.folbigginquiry.justice.nsw.gov.au/Documents/Report \%20of\%20the\%20Inquiry \%20into\%2 0the $\% 20$ convictions $\% 20$ of $\% 20$ Kathleen $\% 20$ Megan\%20Folbigg.pdf $>$ at 48-53 [Inquiry Report].

For a discussion on the issues with the use coincidence and tendency evidence, see the author's submission with colleague Dr. Robert Cavanagh: Injustice Law, Folbigg Submission on Coincidence, online: <https://www.injustice.law/2021/08/19/folbigg-submission-on-coincidence/> [Coincidence]. 
four deaths could not be a coincidence because there were "striking similarities" to the deaths; and that Ms. Folbigg had a tendency to become stressed and smother her children. ${ }^{107}$ It was acknowledged in one of Ms. Folbigg's appeals to the Court of Criminal Appeal that had the counts been heard separately, a verdict of guilty could not be found for the individual charges because the prosecution could not have proved its case beyond reasonable doubt. ${ }^{108}$ This demonstrates the heavy reliance placed on tendency and coincidence evidence by the prosecution to argue it's case in the absence of any pathological evidence to support smothering.

The prosecution's case theory was based largely on Meadow's Law. This was the name given to the dogma espoused by Sir Roy Meadow, a once prominent British paediatrician, who hypothesised that "one infant death is a tragedy, two is suspicious and a third is murder until proven otherwise." 109 This doctrine came to prominence in the United Kingdom in the 1990s after Meadow gave evidence in several trials in which mothers were accused of killing their children. ${ }^{110}$ Mostly notably Meadow gave evidence at the trial of Sally Clark in which he incorrectly stated the chance of two children dying as a result of SIDS was 1 in 73 million. Clark's successful appeal in 2003 found Meadow's evidence to be incorrect. ${ }^{111}$ Other convictions in the United Kingdom based on Meadow's evidence were dismissed. Meadow's Law had been discredited before Kathleen Folbigg's trial commenced in 2003. ${ }^{112}$

Although the prosecution in Ms. Folbigg's trial did not cite Meadow's Law verbatim, it nevertheless found its way into the court room and set the tone for the entirety of the court

This submission was provided to the Attorney General and Governor as part of the Petition for Pardon of Ms Folbigg. The Petition was submitted by the author and Dr. Robert Cavanagh in March 2021 which is still with the Attorney General to provide advice to the Governor about how to act.

${ }^{107}$ Coincidence, supra at note 106.

${ }^{108}$ Justice Hodgson (with Sully and Buddin JJ agreeing) said, inter alia, “"[f]urthermore, my own view is that, on following that course in relation to each count, there would be a deficiency of proof of guilty in relation to each count without evidence concerning the other children...", see $R v$ Folbigg, [2003] NSWCCA 17 at [32].

109 This dogma is said to originally came from American pathologists Dominick DiMaio and Vincent DiMaio. The theory was stated by Meadow in his book ABC of Child Abuse $3^{\text {rd }}$ ed (London: BMJ Books, 1997). For more on Meadow's Law, see the two-part series produced by Discovery Channel entitled "The Baby Killer Conspiracy" about the cases of Sally Clark, Angela Cannings and Kathleen Folbigg which aired on 20 November 2021 (available via UK Discovery+ and UK Amazon).

${ }^{110}$ Including the cases of Sally Clark, Angela Cannings, Trupti Patel and Donna Anthony in the United Kingdom.

${ }^{111}$ See General Medical Council v Meadow, [2006] EWCA Civ 1390. See also the report of Professor Philip Dawid in which he labelled the statistical evidence by Roy Meadows as "highly misleading and prejudicial" in his report, Expert report for Sally Clark Appeal, online:

$<$ https://www.statslab.cam.ac.uk/ apd/>.

${ }^{112}$ See the successful appeal of Sally Clark, $R v$ Clark, [2003] EWCA Crim 1020. Trupti Patel and Angela Cannings are another two women convicted of killing their infant children ( 3 and 2 respectively), in which Meadow also gave evidence at their trials. They were acquitted in June 2003 and December 2003, respectively. 
proceedings. The prosecution case revolved around a key proposition: four natural infant deaths in one family had never been reported or observed before; therefore, it was impossible to have happened in this case. At Ms. Folbigg's committal proceedings, ${ }^{113}$ the report of Dr. Janice Ophoven (a forensic pathologist from the United States) was used, in which she said: "[f]orensic standards of practice would not allow for consideration of a second diagnosis of SIDS after a second sudden death and by the time a third child has died, the death must be investigated as a homicide." 114 She also stated (which she later retracted) that four SIDS deaths in one family is a one in a trillion statistical likelihood; and she encouraged the court to reason that "multiple infant homicides within one family are now well documented in the literature and in forensic experience." "115 This, along with other evidence on the rarity of multiple natural infant deaths, dominated the tone of the committal hearing which ultimately committed Ms. Folbigg to trial in the NSW Supreme Court and formed a backbone of judicial reasoning to permit tendency and coincidence evidence. ${ }^{116}$

While no statistical evidence was given at Ms. Folbigg's trial, three expert witnesses for the prosecution gave evidence that they were not aware of a case of three or more natural infant deaths in the one family. Professor Peter Herdson, Professor Peter Berry and Dr. Susan Beal said they were not aware (from their experience or the literature) of a case of three or more natural infant deaths in the one family. ${ }^{117}$ Almost 16 years later, at the Inquiry into Ms. Folbigg's convictions in 2019, it was revealed that literature existed prior to 2003 documenting multiple infant deaths in some families; ${ }^{118}$ therefore, it can be concluded that the above experts' testimony was inaccurate. The rarity of multiple natural infant deaths as explained by expert witnesses at Ms. Folbigg's trial could have been formative to the jury's understanding of the possibility that four natural deaths could have occurred in this specific instance.

${ }^{113}$ A committal proceeding is a preliminary hearing which determines if there is enough evidence for a trial to go ahead, see Ugur Nedim, What are Committal Hearings?, online:

$<$ https://nswcourts.com.au/articles/what-are-committal-hearings/>.

${ }^{114}$ Report of Dr. Janice Ophoven dated 6 October 2000, see Pathology Tender, supra at note 99. Note: Dr. Ophoven did not give evidence at Ms. Folbigg's trial, only at the committal hearing.

${ }^{115} \mathrm{Ibid}$; Interestingly, in the analogous case of Carol Matthey in Victoria who was charged with smothering her children, Coldrey J expressed many concerns with the evidence given by Dr. Ophoven (of which were very similar to Ms. Folbigg's case). The prosecution in Matthey's case relied on the opinions of Dr. Ophoven, Dr. Cala and Dr. Beal, all of whom featured in Ms. Folbigg's case for the prosecution. Carol Matthey's case did not proceed to trial, see $R v$ Matthey, (2007) 17 VR 222.

${ }^{116}$ Coincidence, supra at note 106.

${ }^{117}$ Aside from the fact that issues arise in expert's population sample in their capacity to answer the question properly, there was in fact literature at the time which documented three or more deaths from SIDS in the one family, see Inquiry Report, supra note 106 at 126-40. Interestingly, Dr. Beal published an article in 1988 in which she reported such a case yet gave evidence to indicate had never heard of such a case, see S M Beal \& H K Blundell, "Recurrence incidence of sudden infant death syndrome" (1988) 63:8 ADC 924 at $927-8$.

118 The Inquiry identified several articles which existed before 2003, see Inquiry Report, supra note 106 at 126-40. 
The rarity of multiple infant deaths was emphasised in a facetious and ill-suited analogy by the prosecutor, Mark Tedeschi, when he made the following remark in his closing address to the jury:

Caleb may have died from a floppy larynx or SIDS. Patrick may have had an ALTE, which was a first epileptic attack or encephalitis. His death may have been caused by an epileptic attack, an epileptic seizure. Sarah may have had a displaced uvula or SIDS. Laura may have died of myocarditis. Well, yes, ladies and gentlemen, I can't disprove any of that, but one day some piglets might be born from a sow, and the piglets might come out of the sow with wings on their back, and the next morning Farmer Joe might look out the kitchen window and see these piglets flying out of his farm. I can't disprove that either. I can't disprove that one day some piglets might be born with wings and that they might fly. Is that a reasonable doubt? No. Is the hypothesis that the defence advances a reasonable doubt? No. Why not? Because if you look at what they are suggesting, not in isolation, but in totality: There has never ever been before in the history of medicine that our experts have been able to find any case like this. It is preposterous. It is not a reasonable doubt. It is a fantasy, and of course the Crown does not have to disprove a fanciful idea. ${ }^{119}$

This in effect created a default position that the children's deaths must be murder: four children dying of natural causes in one family had never happened before; and because of this, the natural causes of death at autopsy given by experts must, therefore, constitute a "fantasy". Meadow's Law reasoning and incorrect evidence about the absence of cases of multiple recurrent natural infant deaths in a family resulted in the effective reversal of the onus of proof: Ms. Folbigg was required to demonstrate natural causes because the default position was murder.

In criminal trials in NSW, the prosecution is required to prove their case beyond reasonable doubt. ${ }^{120}$ This includes negativing any reasonable possibility consistent with innocence. ${ }^{121}$ It was not the role of the defence in this case to prove natural causes. It is clear from the passage above the prosecution was aware it was unable to negate the natural causes of death as diagnosed at autopsy for each child. Because of the application of Meadows Law reasoning to the tendency and coincidence arguments admitted at trial, this also became part of Ms. Folbigg's appeals. ${ }^{122}$

Ms. Folbigg's private diaries and journals featured prominently in the prosecution case. Ms. Folbigg's kept diaries/journals since she was about 10 years of age. She wrote in a few diaries/journals over the period of 10 years of her children's lives and deaths. Two of them were handed in by Ms. Folbigg's husband after she initiated a separation from him; he said he discovered

${ }^{119}$ Trial Transcripts, supra note 105 at 1375 (emphasis added).

${ }^{120}$ Evidence Act 1995 (NSW), s 141(1).

${ }^{121}$ A reasonable possibility consistent with innocence needs to be negatived by the prosecution before an individual can be found guilty of a criminal offence, see Moore v R, [2016] NSWCCA 185 at [43], [94], [125]; Pell v The Queen, [2020] HCA 12 at [42].

${ }^{122}$ Coincidence, supra at note 106. 
the diaries/journals and claimed he was troubled by what he read in them. ${ }^{123}$ The prosecution selected a handful of entries from the corpus of her writings (which comprise well over fortythousand words total) to suggest they were admissions of murdering her children. ${ }^{124}$ Indeed, the prosecution said that cherry-picked entries were the "strongest evidence the jury could possibly have for Ms. Folbigg having murdered her four children." ${ }^{25}$ Ms. Folbigg has always maintained she never harmed her children and her entries were reflective of her guilt feelings for not being a good enough mother. ${ }^{126}$

Ms. Folbigg was ultimately convicted of one count of manslaughter, one count of grievous bodily harm and three counts of murder. She has appealed several times. In 2005, Ms. Folbigg appealed to the Court of Criminal Appeal on four points: (1) that the five charges should not have been heard together; (2) the jury verdicts were unreasonable and could not be supported by the evidence; (3) prosecution experts said that they were unaware of previous cases in which three or more infants in one family died suddenly, and this was wrong; (4) the judge did not properly direct the jury about tendency and coincidence evidence. ${ }^{127}$ She was unsuccessful and sought special leave from the High Court of Australia in 2005 to challenge this decision. That request was denied. ${ }^{128}$ She then appealed again in $2007^{129}$ to the Court of Criminal Appeal on the basis that jurors had obtained the following information at trial: (1) that Ms. Folbigg's father killed her mother, and (2) the generalised length of time that an infant's body remains warm after death. Ms. Folbigg said those two points impacted on the jury's decision. ${ }^{130}$ She was unsuccessful in this appeal.

After having exhausted her court appeals, in June 2015, she first engaged the postconviction review system. Ms. Folbigg's legal representatives petitioned the Governor requesting a review of her convictions. ${ }^{131}$ A strong basis for which she requested a review was centred on a report from leading forensic pathologist, Professor Stephen Cordner. He reviewed all the forensic pathology evidence and concluded that there is "no forensic pathology support for the contention that any or all of these children have been killed, let alone smothered." 132 The petition also

${ }^{123}$ Trial Transcripts, supra note 105 at 180.

${ }^{124}$ See Inquiry Report, supra note 106 at 365-77 for a summary of the entries used by the prosecution at trial.

${ }^{125}$ Trial Transcripts, supra note 105 at 1372; Inquiry Report, supra note 106 at 74 [145].

${ }^{126}$ For a full copy of Ms. Folbigg's journals and diaries, along with a copy of her Electronically Recorded Interview (ERISP) with police from 1999, see Inquiry into the Convictions of Kathleen Megan Folbigg,

Diaries Tender Bundle (Exhibit AZ), online:

<https://www.folbigginquiry.justice.nsw.gov.au/Documents/Exhibit\%20AZ\%20-

\%20Diaries\%20tender\%20bundle.pdf> [Diaries Tender].

${ }^{127} R v$ Folbigg, [2005] NSWCCA 23 which was an appeal against conviction and sentence.

${ }^{128}$ Folbigg $v R$, [2005] HCA Trans 657.

${ }^{129}$ She sought leave to appeal, which was granted, see Folbigg $v R$, [2007] NSWCCA 128.

${ }^{130}$ Folbigg $v$ R, [2007] NSWCCA 371.

${ }^{131}$ See, Injustice Law, Petition to the Governor for Review, online:

<https://www.injustice.law/2015/05/15/folbigg-petition-to-governor-for-review/>.

${ }^{132}$ Report of Professor Stephen Cordner, online: 
demonstrated that knowledge about sudden infant death had advanced considerably since 2003. Attorneys General Gabrielle Upton (over two years) and then the current NSW Attorney General Mark Speakman (over a year) delayed acting on this petition for a total of approximately three years and two months. In August 2018, nine days after an Australian Broadcasting Company (ABC) program aired its investigation of Ms. Folbigg's case, ${ }^{133}$ an inquiry was announced by Mr. Speakman.

From March 2019, three weeks of hearings were held in which evidence was presented in the areas of forensic pathology, immunology and infection, cardiology, neurology, and genetics. ${ }^{134}$ Ms. Folbigg also gave evidence over three days concerning her diaries/journals. ${ }^{135}$ Despite genetic and medical evidence establishing a natural cause of death for each child, the Commissioner (retired judge Reginald Blanch) concluded that he had no reasonable doubt as to Ms. Folbigg's convictions, and was "even more certain" of her guilt based on her "explanations and behaviour in respect of her diaries." 136 This was so despite three eminent forensic pathologists agreeing on a natural cause of death for each child, five experts in genetics and cardiac arrythmias agreeing on the likelihood of a genetic mutation in the CALM2 gene causing the death of Sarah and Laura, other experts opining on the interconnected role other matters played in the deaths (for example, infection in Sarah Folbigg), and no forensic evidence of smothering. The Commissioner said the only reasonable conclusion open to him is that Ms. Folbigg smothered all four children. ${ }^{137}$ This conclusion, however, runs counter to the medical and scientific evidence presented to the Inquiry.

In March 2021, the author of this article along with her colleague Dr. Robert Cavanagh (barrister) submitted a petition requesting the Governor exercise the Royal Prerogative of Mercy and pardon Ms. Folbigg. ${ }^{138}$ This petition was based on the fact there is no evidence of smothering and only natural causes of death (supported by fresh genetic evidence obtained in November

<https://www.folbigginquiry.justice.nsw.gov.au/Documents/Exhibit\%20Q\%20\%20Expert\%20report\%20of\%20Professor\%20Stephen\%20Cordner.PDF> at 7.

${ }^{133}$ The program, entitled 'From Behind Bars' can be viewed here online: <https://www.abc.net.au/austory/from-behind-bars/10105090>.

${ }^{134}$ See, Inquiry into the Convictions of Kathleen Megan Folbigg, Exhibits, online: $\langle$ https://www.folbigginquiry.justice.nsw.gov.au/Pages/exhibits.aspx $>$.

135 Transcripts of all hearing days, including the three days in which Ms Folbigg gave evidence can be found here: Inquiry into the Convictions of Kathleen Megan Folbigg, Transcripts, online:

〈https://www.folbigginquiry.justice.nsw.gov.au/Pages/transcripts.aspx >.

${ }^{136}$ Inquiry Report, supra note 106 at 480 [89].

137 "It remains that the only conclusion reasonably open is that somebody intentionally caused harm to the children, and smothering was the obvious method. The evidence pointed to no person other than Ms Folbigg" Inquiry Report, supra note 106 at 480 [88].

138 The Petition for Pardon can be viewed here: Australian Academy of Science, online:

$<$ https://www.science.org.au/files/userfiles/events/news/documents/petition-to-governor-of-nsw-forpardon-of-kathleen-folbigg-05-03-21.pdf>; This petition was requested under s 76 of the Act requesting the Governor exercise the pardon power and release Ms Folbigg immediately. Note: a successful pardon does not remove Ms Folbigg's convictions; she would need to go to the Court of Criminal Appeal to have her convictions quashed. 
2020). ${ }^{139}$ This petition was backed 90 eminent scientists, medical practitioners and prominent science advocates, including Professor John Shine, President of the Australian Academy of Science; Nobel Prize Laureates Professors Peter Doherty and Elizabeth Blackburn; Former Chief Scientist of Australia Professor Ian Chubb, leading Australian of the Year researchers Professors Fiona Stanley and Ian Frazer and three of the world's most distinguished cardiologists and/or cardiac geneticists, Professors Peter Schwartz, Christopher Semsarian and Reza Razavi. A further 66 members of the Royal Society of NSW, including the then President, Professor Ian Sloan, have since put their name to support the petition.

The extraordinary scientific support of the petition was, in large part, due to the genetic evidence of the cardiac mutation (CALM2) found in Sarah and Laura Folbigg. A study was performed by Professors Peter Schwartz, Michael Toft Overgaard, Carola Vinuesa and a team of 24 scientists across the world in multiple labs and was published in a peer-reviewed study in the prestigious Oxford University Journal, EP Europace ("Europace"). The study concluded that the cardiac mutation (the CALM2 mutation) was a reasonable and likely cause of Sarah and Laura's deaths. ${ }^{140}$ This, combined with the fact there was no evidence of smothering, and only natural causes of death for all four children determined by autopsy, makes the case for a pardon in this instance compelling. ${ }^{141}$ Ms. Folbigg is currently waiting for Attorney General Mr. Speakman to provide advice to the Governor about how she should act in relation to the petition.

Below, the article identifies some matters observed in Ms. Folbigg's Inquiry in 2019 which raise questions about the extent to which post-conviction review is independent, transparent, and accountable in NSW.

\section{The issues with the review in Ms. Folbigg's case}

The issues with Ms. Folbigg's review process will be discussed chronologically from when the petition was initially submitted to the Governor asking for review in June 2015 through to the outcome of the Inquiry in July 2019.

\footnotetext{
139 Malene Brohus et al, "Infanticide vs. inherited cardiac arrhythmias" (2021) 23:3 EP Europace 441, online: 〈https://academic.oup.com/europace/article/23/3/441/5983835>.

${ }^{140}$ Ibid.

${ }^{141}$ NSW Government Communities \& Justice Fact Sheet on the Royal Prerogative of Mercy states that "some examples of extraordinary circumstances in which pardons have been granted include wrongful convictions, where new methods of forensic evidence raise significant questions as to the petitioner's guilt...", see NSW Government, Communities \& Justice, Royal Prerogative of Mercy Factsheet March 2021, online:

<https://www.justice.nsw.gov.au/justicepolicy/Documents/royal-prerogative-mercy-review-terms-ofreference.pdf>.
} 


\section{A. Lack of legal timeframes}

There is no legislative timeframe in which the decision maker must decide whether or not a petition or application is to be granted. ${ }^{142}$ There is also no clear timeframe for when an inquiry is to commence after the approval of review. ${ }^{143}$ At the conclusion of an inquiry, the Commissioner must send a report of her/his findings to the Governor or Chief Justice of the Supreme Court. Once again, there is no timeframe provided for this.

There are many examples of legislation which do not provide a specific timeframe for decision making. In some instances, however, legislation requires a decision to be made within a "reasonable time." 144 The importance of having a "reasonable time" mandated, at bare minimum, is to ensure that the person who is seeking to invoke their rights at law has some certainty of when a decision is likely to occur. There are general administrative law remedies that allow for a decision-maker to be ordered to make a decision; ${ }^{145}$ however, these are often complex and are discretionary in nature. While there is a need for these remedies, having certainty of timeframe in the first instance might avoid the need to engage in seeking remedies in administrative law as they can have the effect of holding decision makers to account.

In the case of Ms. Folbigg, it took three years and two months for the Attorney General's office to recommend an inquiry be established. There were no reasons provided to explain such an inordinate delay. While the inquiry was established quickly after it was announced, the lack of a timeframe could lead to delay in other cases. In the case of the Commissioner's report being sent to the Governor, this was done expeditiously, although without the safeguard of a timeframe, this too could be problematic in future cases.

A lack of clearly defined time expectations is a transparency and accountability issue; the public ought to be aware of when decisions will be provided especially in circumstances in which a person's liberty is affected.

\section{B. Selection of Commissioner and Counsel Assisting}

A Commissioner is appointed by the Governor ${ }^{146}$ or the Chief Justice of the Supreme Court $^{147}$ after an inquiry is ordered. In Ms. Folbigg's case, Commissioner Reginald Blanch was appointed. Mr. Blanch was the first Director of Public Prosecutions in NSW and served in that

${ }^{142}$ Anecdotally, the author was informed by a colleague that they had made an application to the Supreme Court requesting a review on behalf of a woman convicted of murder. The application was submitted in July 2011 and they received a denial in September 2013. This furthers the argument in the body of the paper that a lack of legal timeframe can lead to inordinate delay.

${ }^{143}$ An inquiry is to be established "as soon as practicable": s 80 of the Act.

${ }^{144}$ A reasonable time is used frequently in contract law.

${ }^{145}$ See, for example, the writ of mandamus: Australian Law Reform Commission, A Common Law

Principle, online: <https://www.alrc.gov.au/publication/traditional-rights-and-freedoms-encroachmentsby-commonwealth-laws-alrc-report-129/15-judicial-review/a-common-law-principle-13/>.

${ }^{146}$ Crimes Act, supra note 17 at s 81(1)(a).

${ }^{147}$ Ibid s 81(1)(b). 
capacity from 1987 to 1994. During Mr. Blanch's time as Director, the Crown Prosecutor of Ms. Folbigg's trial, Mark Tedeschi, was appointed to the role of Deputy Senior Crown Prosecutor. Mr. Blanch was also the Chief Judge of the NSW District Court from 1994 to 2014. Gail Furness, a senior barrister with some experience in inquiries, was appointed to the role of Counsel Assisting Ms. Folbigg's Inquiry. No reasons were given for why Mr. Blanch and Ms. Furness were selected for this Inquiry.

The appointment of Commissioners and Counsel Assisting in inquiries is currently not transparent. There is no statutory appointment process or publicly available information to indicate if there is a tender process (or similar) undertaken to select the best candidate. The lack of openness around the selection of a Commissioner and Counsel Assisting raises issues of independence and transparency in who is selected and on what basis.

\section{The Commissioner's broad discretion in the Inquiry process}

The Commissioner conducting an inquiry is given the powers, authorities, protections and immunities afforded to Commissioners of Royal Commissions (which are usually established to investigate systemic and wide-reaching issues). ${ }^{148}$ Justice Peter M. Hall, as he then was, said that "documented guidelines are often drafted and as necessary periodically revised" in relation to the due and proper exercise of expansive powers by an inquiry. ${ }^{149}$ Although in the Folbigg Inquiry, to the author's knowledge, there were no documented guidelines of the kind described.

The following passages analyse how the Commissioner of Ms. Folbigg's Inquiry exercised his discretion and considers how the use of discretion affects the fairness of the post-conviction review process. The matters outlined below are issues that go to the procedure of the Inquiry; these ultimately highlight the deficiency in the law to give certainty to what can and cannot, and indeed should or should not, be done. These matters concern the transparency and accountability of an inquiry process.

\section{a. Scope of Inquiry}

There is no specific law that gives power to a Commissioner to either restrict or extend the scope of an inquiry outside of that which is mentioned in the formal direction from the Governor/Supreme Court in ordering the inquiry. ${ }^{150}$ It appears that Commissioners interpret the terms from the formal direction; this interpretation becomes the scope of the investigation. ${ }^{151} \mathrm{In}$ 2018, the Governor ordered an inquiry into Ms. Folbigg's convictions to investigate evidence "as to the incidence of reported deaths of three or more infants in the same family attributed to unidentified natural causes." $" 152$

\footnotetext{
${ }^{148}$ Royal Commissions Act 1923 (NSW) Division 1, Part 2: s 81(2)(a).

${ }^{149}$ Hall, supra note 42 at 31.

${ }^{150}$ This point requires further research and is outside the scope of this paper.

${ }^{151}$ Hall, supra note 42 at 29.

${ }^{152}$ See Inquiry into the Convictions of Kathleen Megan Folbigg, Exhibit A, online: $<$ https://www.folbigginquiry.justice.nsw.gov.au/Documents/exhibit-a-governor-direction-tendered-atdirections-hearing-held-on-25-October-2018.pdf>.
} 
The Commissioner of the Inquiry determined the scope of the Inquiry to include medical evidence and non-medical evidence, including Ms. Folbigg's diaries and evidence from her about them. Very little attention was paid to the conduct of Ms. Folbigg's trial and the treatment by the prosecution of the cherry-picked diary entries in those proceedings. This included a lack of attention to prosecutor's conduct and how this might have influenced the jury decision. ${ }^{153}$ The Commissioner also advised Ms. Folbigg's representatives that he did not want a psychiatric report to advise him how to interpret Ms. Folbigg's diaries. ${ }^{154}$ This meant that Ms. Folbigg's diaries were not properly contextualised; therefore, the Inquiry only considered a singular, inculpatory interpretation of the cherry-picked entries. ${ }^{155}$ The Commissioner's determination of the scope of the Inquiry led to a narrow view of the possible issues in relation to Ms. Folbigg's convictions.

\section{b. "Hot tubbing" experts and treatment of expert witnesses}

Ms. Folbigg's Inquiry adopted a style of expert questioning that is foreign to most criminal procedures in Australia. "Hot tubbing" refers to the process when experts give evidence together in a group setting. It might have some utility, for example, when there is a need to understand tensions or novel points in a field of expertise that could not be adequately addressed in pre-trial conferences. In this instance, however, hot tubbing limited the proper testing of the evidence. Some experts were not permitted to give comprehensive answers to questions asked (instead being required to answer with a simple "yes" or "no"). ${ }^{156}$ Some experts were also not asked the same

${ }^{153}$ Brief reference in the Inquiry Report to the prosecutor's conduct (see pages 109-112) does not constitute a full and proper consideration; yet despite this the Commissioner concluded that he found the conduct of the prosecutor did not cause a "procedural irregularity or an error in the trial process..." see Inquiry Report, supra note 106 at 111 [391].

${ }^{154}$ See Inquiry into the Convictions of Kathleen Megan Folbigg, Transcript 20 March 2019, online: <https://www.folbigginquiry.justice.nsw.gov.au/Documents/FINAL\%20\%20Transcript\%20of\%2020\%20March\%202019.pdf> 354-55 [Transcript 20 March].

${ }^{155}$ Daily Telegraph, supra at note 6. 60 Minutes, supra at note 6.

${ }^{156}$ Instances where Counsel Assisting Gail Furness advised the witnesses to answer her question: see e.g., Inquiry Transcript 19 March 2019 page 78 line 5; Transcript 20 March 2019 page 146 line 40. The Commissioner also requested that witnesses simply answer the question they were asked: Inquiry Transcript 22 March 2019 page 320 line 5; and by Counsel Assisting on page 322 line 35 and line 45; page 347 line 40 where Counsel Assisting said to a witness "No, just answer the question, am I right or wrong". The Commissioner also cautioned the forensic pathologists in attendance to focus their answers and not "talk unnecessarily" because things got "discursive" on the previous day: Inquiry Transcript, 21 March 2019, page 241 line 15 and line 20, online:

〈https://www.folbigginquiry.justice.nsw.gov.au/Pages/transcripts.aspx $>$. The issue of not permitting an expert to give a comprehensive answer rises where complex evidence is being examined; precision and explication is required from the witness for the court to understand the issues properly. Limiting the witness to a yes or no is not appropriate in the context of an inquiry process, although it may be appropriate in cross examination in adversarial proceedings. 
follow up questions that others were asked. ${ }^{157}$ The way in which the questioning occurred, featuring the limitations as mentioned, meant that experts were not able to respond comprehensively to the questions asked. This had the practical effect of reducing the range and depth of expert opinion provided to the Inquiry. These issues highlight the procedural limitations of hot tubbing when compared with examination of a witness on their own.

Another aspect that influenced the Inquiry's comprehensive review of Ms. Folbigg's convictions was the differential treatment of witnesses. One example was the early invitation by Counsel Assisting for geneticists Professor Carola Vinuesa and Dr. Todor Arsov (engaged by Ms. Folbigg's representatives) to leave the hearing. The other "team" of geneticists ("the Sydney Team"; engaged by the Inquiry) were not invited to leave and they subsequently remained to hear and respond to the evidence of two neurologists. There was no reason given for Counsel Assisting's invitation for Professor Vinuesa and Dr. Arsov to leave, and this was not challenged or questioned by the Commissioner. Conceivably, Professor Vinuesa and Dr. Arsov might have given further evidence, as the other team did. The absence of Professor Vinuesa and Dr. Arsov might have had an impact on the comprehensive understanding of the relationship between genetics and neurology, particularly in relation to the death of Patrick Folbigg. The Inquiry hearing from Professor Vinuesa and Dr. Arsov is also a matter of procedural fairness to Ms. Folbigg.

\section{c. Redactions of evidence}

In Royal Commissions and special inquiries established to review convictions, ${ }^{158}$ the normal rules of evidence applied to criminal proceedings do not apply. This is because the scope of an inquiry necessitates consideration of a broad range of material; this is in line with the purpose - a search for the truth as opposed to an adversarial litigious proceeding. It is for the Commissioner to determine what she/he will receive and require to investigate the matter fully. In this regard "there is...a well recognised adaption by commissioners of those principles to which judges and jurors traditionally resort when engaged upon critical process of fact finding." ${ }^{159}$ It is also well established that procedural fairness is required in inquiries. ${ }^{160}$

There is no law which dictates who is responsible for the tendering of evidence at an inquiry; however, Counsel Assisting undertook that role at Ms. Folbigg's Inquiry. It was assumed that the actions of Counsel Assisting in all respects were approved by the Commissioner as he

\footnotetext{
${ }^{157}$ Professor Stephen Cordner was placed on the other side of the room away from Professors Hilton and Duflou and Dr. Cala who were seated on the other side of the room (there was quite some distance between the two seating areas). At times during the questioning by Counsel Assisting, Professor Cordner was not asked his thoughts on matters the other three forensic pathologists were asked, see Inquiry Transcripts from 19, 20 and 21 March 2019, online: $\langle$ https://www.folbigginquiry.justice.nsw.gov.au/Pages/transcripts.aspx $>$.

${ }^{158}$ These investigative mechanisms are not legally binding, they provide recommendations.

${ }^{159}$ Australia, Report of the Royal Commission into an Attempt to Bribe a Member of the House of Assembly and Other Matters (Tasmania, 1991) vol at 37 cited in Hall, supra note 42 at 30.

${ }^{160}$ See e.g., Ainsworth v Criminal Justice Commission, [1992] HCA 10.
} 
made no objection. ${ }^{161}$ Counsel Assisting's role in inquiries generally has been recognised as having the responsibility to "elicit material in the fullest and fairest manner in relation to the subject matter of the inquiry." "162

Emeritus Professor Robert Clancy, a world recognised immunologist, was engaged by Ms. Folbigg's legal representatives to give evidence at the Inquiry. His expertise was in SIDS, immunology and infection. He gave opinions about the role of such in understanding the deaths of the Folbigg children. During his evidence, he was invited by Counsel Assisting to respond to a report from Professor Rosemary Horne (engaged by the Inquiry, who gave evidence about SIDS risk factors) by way of a further report. ${ }^{163}$ Professor Clancy did so; yet upon receipt, all relevant opinions given by him on Professor Horne's report were redacted. Those portions redacted directly questioned the reliability and currency of Professor Horne's evidence and therefore, the weight that ought to be ascribed to it. No reasons were given as to why this occurred or who redacted the evidence. These redactions were made without any consultation with Ms. Folbigg's representatives or Professor Clancy. ${ }^{164}$

Redactions were also made to a report of Professor Paul Goldwater, an expert on infection in SIDS, engaged by Ms. Folbigg's representatives (although he was not invited to give evidence at the Inquiry). Professor Goldwater provided a review of the opinions offered by Professor Caroline Blackwell (microbiologist) and Professor Robert Clancy in relation to SIDS, infection and immunology. He also commented on the approach of other experts at trial in relation to these fields of expertise. The redacted portions of the report related to his questioning of the reliability and accuracy of evidence given at trial, which were entirely open for Professor Goldwater to make based on his experience and qualifications. ${ }^{165}$ It was in Ms. Folbigg's interests for the report to be tendered in full. It is unclear who redacted this evidence.

161 "The Commission may conduct hearings. At those hearings the Commissioner who is presiding is empowered to require a person to answer questions. Although the questions may be asked by another, the Act contemplates counsel assisting, nevertheless each question is asked with the authority of the Commissioner. The Commissioner is charged with the function of ensuring that the questions are fair to the witness and that procedural fairness is afforded to that person" see $R v \operatorname{Vos}$ (2011), 223 A Crim R 316 at [36] (McClellan CJ at CL with Hidden and Johnson JJ agreeing) which was also cited as good authority in the case of McCloy $v$ Latham, [2015] NSWSC 1897 at [97] (McDougall J).

${ }^{162}$ Hall, supra note 42 at 32.

${ }^{163}$ See Inquiry into the Convictions of Kathleen Megan Folbigg, Transcript 22 March 2019, online:

$<$ https://www.folbigginquiry.justice.nsw.gov.au/Documents/FINAL\%20-

\%20Transcript\%20of\%2022\%20March\%202019.pdf> at 331 line 25.

${ }^{164}$ Redacted report of Professor Robert Clancy dated 27 March 2019, online:

<https://www.folbigginquiry.justice.nsw.gov.au/Documents/Exhibit\%20AT\%20-

$\% 20$ Additional $\% 20$ expert $\% 20$ report $\% 20$ of $\% 20$ Professor $\% 20$ Robert $\% 20 \mathrm{Clancy} \% 20$ dated $\% 2027 \% 20 \mathrm{Mar}$ ch\%202019.PDF>.

${ }^{165}$ Redacted report of Professor Paul N Goldwater dated 29 March 2019, online:

<https://www.folbigginquiry.justice.nsw.gov.au/Documents/Exhibit\%20AU\%20-

\%20Expert\%20report\%20of\%20Professor\%20Paul\%20Goldwater\%20dated\%2029\%20March\%202019.

PDF>. 
The wide powers afforded to the Commissioner and Counsel Assisting in Ms. Folbigg's Inquiry led to important evidence not being admitted formally to the Inquiry. It was unclear to those representing Ms. Folbigg whether it was Counsel Assisting, Gail Furness, who redacted the opinions of Professors Clancy and Goldwater, or if this was requested by the Commissioner after he received it. The importance of clear and well-understood procedures for dealing with evidence was revealed by the redaction of potentially vital expert evidence that could have impacted the Commissioner's comprehensive assessment of evidence specifically, and in totality.

In the context of a Royal Commission, broad discretionary powers might be appropriate given the scale often associated with an inquiry of large proportion, ${ }^{166}$ such as one in which a systemic issue such as child sexual abuse in institutions is being investigated. The need for extraordinary powers in these circumstances might be suitable, e.g., the need to compel witnesses to give evidence and the power to redact certain material to protect vulnerable persons. When a special inquiry is established for the purpose of investigating an individual's conviction, as in the case of Ms. Folbigg, these powers might not be appropriate, because the scale and objective(s) are necessarily different. In this case, the redactions to material evidence might have affected the assessment of all the evidence by the Commissioner and the ultimate fairness of the outcome to Ms. Folbigg.

\section{d. Refusal to consider Ms. Folbigg's diaries in context}

Commissioner Blanch indicated he did not want an expert to assist him in understanding Ms. Folbigg's diaries or her mental state at the time of writing:

... I would not be assisted at all in this Inquiry by a psychiatrist who wanted to come along and tell me (a) what the words of the diary mean or (b) about the fact that a mother who had lost her babies would be upset and emotional and so on. Those are things that are readily apparent, I think, unless there is some other aspect of it. ${ }^{167}$

Through these comments and reminders by him that context "is irrelevant", ${ }^{168}$ the Commissioner restricted Ms. Folbigg's evidence and did not allow her to give comprehensive evidence about her state of mind at the time she wrote her diaries/journals. The Commissioner said that the diaries/journals must be interpreted on the words only; on their "ordinary English meaning" or "plain meaning." "169 The discretion afforded to the Commissioner to restrict Ms. Folbigg's evidence led to a highly limited understanding of what she wrote in her diaries/journals. This is particularly problematic given the fact that the Commissioner focused disproportionately

\footnotetext{
${ }^{166}$ See generally, Scott Prasser, Royal Commissions and Public Inquiries in Australia (Chatswood, NSW: LexisNexis Butterworths, 2006).

${ }^{167}$ Transcript 20 March, supra note 154 at 354-55.

168 For example, The Commissioner said "Well, I must say that I take the view...that the context is irrelevant.", see Inquiry into the Convictions of Kathleen Megan Folbigg, Transcript 29 April 2019, online: <https://www.folbigginquiry.justice.nsw.gov.au/Documents/FINAL\%20\%20Transcript\%20of\%2029\%20April\%202019.pdf> at 618-19 [Transcript 29 April].

${ }^{169}$ Inquiry Report, supra note 106 at 447-9.
} 
on the diaries/journals and Ms. Folbigg's evidence in relation to them; he used these to conclude he had no reasonable doubt about her convictions. Recent expert opinion (of the kind Commissioner Blanch advised he did not want) from this year has revealed that context is highly relevant to explanations from people about their private writings, but more importantly, only the author can interpret their own private writings. ${ }^{170}$

The determination of what is relevant, like the power to redact potentially important information, demonstrates a deficiency in the way in which inquiry procedure is currently structured. The denial by the Commissioner to be guided by relevant expert opinion also calls into question the transparency of inquiry procedure in relation to what is deemed relevant evidence. These factors can ultimately affect the fairness of outcomes.

\section{e. Leave to appear at the inquiry}

All parties wanting to appear at an inquiry must be granted leave. There is a requirement that a person whose character might be affected during inquiry proceedings to be granted leave to question witnesses. ${ }^{171}$ It has obvious necessity; if a person's character is called into question by evidence given at an inquiry, natural justice necessitates that the person be present to meet that challenge. ${ }^{172}$ It is reasonable to conclude that the wording of the provision means that questioning of a witness for this purpose would be restricted to that which might affect her/his character or reputation.

At the Inquiry, Ms. Margaret Cunneen (Counsel for Mr. Folbigg, Kathleen Folbigg's exhusband) was granted leave to appear and permitted to cross examine Ms. Folbigg for approximately a day and a half about her diaries/journals. The line of questioning by Ms. Cunneen only focussed on Ms. Folbigg's diary entries and whether she killed the children, neither of which have anything to do with Mr. Folbigg's character or reputation. ${ }^{173}$ Ms. Cunneen asked Ms. Folbigg approximately 65 times if she had killed the children; Ms. Folbigg denied this on each occasion. Much of her questioning had already been covered in the cross examination by Counsel for the ODPP which preceded. The only mentions of Mr. Folbigg was when Ms. Folbigg gave evidence to say "...I felt like Craig did sleep too easily through a lot and that I just felt like he could've helped out more" 174 and other similar comments about needing his help with the care of the children. In contrast, most of the mentions of Mr. Folbigg by Ms. Folbigg were positive, for example, Ms. Folbigg stated that she knew Craig loved his children and would care for them. ${ }^{175}$

\footnotetext{
${ }^{170}$ Daily Telegraph, supra at note 6. 60 Minutes, supra at note 6.

${ }^{171}$ Crimes Act, supra note 17 at s 81(4).

${ }^{172}$ See e.g., Kioa $v$ West (1985,) 159 CLR 550 at 582 (Mason J), 618-9 (Brennan J); Annetts v McCann (1990), 170 CLR 596 at 608 (Brennan J); Ainsworth v Criminal Justice Commission, [1992] HCA 10 at [27] (Mason CJ, Dawson, Toohey and Gaudron JJ).

173 See Inquiry Transcripts from 29 April 2019, 30 April 2019 and 1 May 2019. Mr. Folbigg's cross examination starts on page 677 of the transcript of 29 March 2019, online:

<https://www.folbigginquiry.justice.nsw.gov.au/Pages/transcripts.aspx >.

${ }^{174}$ Transcript 29 April, supra note 168 at 657 line 5.

${ }^{175} \mathrm{Ibid}$ at 685.
} 
In the normal course of events, cross examination of Ms. Folbigg by Mr. Folbigg's Counsel on such matters would have usually arisen after examination in chief by Ms. Folbigg's representatives. Matters that arose from Ms. Folbigg's evidence in chief, would then be cross examined; however, Ms. Cunneen's questioning immediately followed the cross-examination by Counsel representing the ODPP (who led evidence from Ms. Folbigg first). As Ms. Folbigg was the Inquiry's witness (and not her own representatives' witness as in the case in adversarial proceedings), normal procedure of inquiries/Royal Commissions should have seen Counsel Assisting lead evidence from Ms. Folbigg, as she did with all the other witnesses present at the Inquiry. ${ }^{176}$ Counsel for Ms. Folbigg raised the fact that Mr. Folbigg does not have a general right of cross-examination and any questioning ought to be limited to that which is required to protect his reputation or character only. The Commissioner of the Inquiry disagreed and permitted all the questioning by Ms. Cunneen. ${ }^{177}$

If any questioning were to be allowed, it should have been limited in scope to Mr. Folbigg's helping or not with the children. The Commissioner restricted the scope of Ms. Folbigg's evidence to relate to "strictly... about the diary entries, possession of the diaries and her disposal of the diaries" and "nothing else." 178 This fact makes it highly problematic that the Commissioner permitted Ms. Cunneen to cross-examine the way she did. The questioning by Mr. Folbigg's Counsel demonstrates the significant discretion afforded to the Commissioner of an inquiry.

\section{e. Not reopening hearings to hear further evidence}

It is well recognised that an inquiry is a search for the truth and not a litigious exercise. To that end, Commissioners need to consider all relevant matters that might inform her/his task to the inquiry. The role of Counsel Assisting has also been said to involve the re-calling of witnesses for procedural fairness purposes because the objective is truth seeking. ${ }^{179}$

The Commissioner of the Inquiry did not reconvene the hearings to hear new important evidence relating to a genetic mutation identified in the two female Folbigg children, nor did Counsel Assisting recommend this course of action. During the Inquiry, a cardiac mutation, commonly known as the CALM2 mutation, was identified in Ms. Folbigg and her two daughters Sarah and Laura. There was some contention between the two teams of geneticists as to the lethality of this mutation. Because there was no expert to reconcile this tension, Professor Vinuesa

${ }^{176}$ Without consultation with Ms. Folbigg's representatives, in a private conversation that took place, it was agreed between Counsel Assisting Gail Furness, Christopher Maxwell for the Office of the Director of Public Prosecutions and Margaret Cunneen for Craig Folbigg, what order they would they question Ms. Folbigg, see where Maxwell says "I've discussed it with my learned friend, Ms Cunneen and counsel assisting, Ms Furness, and I'm happy to start my cross-examination sooner rather than later", see Transcript 29 April, supra note 168 at 619 line 10; On the role of Counsel Assisting in this regard, see Peter M Hall, Investigating Corruption and Misconduct in Public Office: Commissions of Inquiry - Powers and Procedures (Law Book Co, 2004) at 673-6.

${ }^{177}$ Transcript 29 April, supra note 168 at 697 lines 10-20.

${ }^{178} \mathrm{Ibid}$ at 618 lines 5 to 10.

${ }^{179}$ John Stowe, "Some notes on natural justice in relation to inquisitorial proceedings" (Seminar at New South Wales Bar Association, 2 November 1992) 7 cited in Hall, supra note 42 at 29. 
contacted the leading expert in calmodulinopathies (caused by mutations in CALM genes), Professor Peter Schwartz. At this stage, the Inquiry hearings had closed. Professor Schwartz wrote to the Inquiry to indicate that the mutation in Sarah and Laura was likely to be lethal. ${ }^{180}$ He pointed to data from the International Calmodulinopathy Registry ("ICalmR") which detailed the death and cardiac arrest of two US siblings with a mutation in the same calmodulin residue - Glycine 114, G114 - as Sarah and Laura. He also pointed out that a portion of deaths caused by CALM genes occurred whilst asleep (Sarah and Laura died during a sleep period), in young children in the ages of Sarah and Laura, and without any previous warnings of symptoms. ${ }^{181}$

This was significant as it changed the way in which the genetic evidence received during the hearings could be assessed. Professor Schwartz and Professor Toft-Overgaard (who endorsed the position of Professors Schwartz and Vinuesa) were the only experts in calmodulinopathies to provide their opinion to the Inquiry; therefore, their evidence should have been given more weight than other expert witnesses who did not have subject matter expertise. To assess the genetic evidence in totality, the hearings should have been reconvened to hear from Professor Schwartz on this issue in formal evidence. This was especially important since the only cardiologist who gave evidence at the Inquiry hearings incorrectly indicated that there was no reported case of asymptomatic sudden cardiac death in infancy during a sleep period associated with a calmodulin variant in young children. The Commissioner relied on the cardiologist's opinion to conclude incorrectly that genetic mutations did not contribute to Sarah or Laura's deaths. ${ }^{182}$ This was in direct contrast to the information provided to the Inquiry by Professor Schwartz based on the data from the ICalmR. The opinion of Professor Schwartz was substantiated by the publication of the Europace paper in November 2020 on the role of this mutation in the deaths of Sarah and Laura. Instead of reconvening the hearings on this important issue, the Commissioner dealt with this evidence in an addendum to his report, ${ }^{183}$ preferring the expertise of the "Sydney Team." This is another example of how broad discretion given to a Commissioner might lead to a restricted approach to evidence.

The Commissioner ultimately found no reasonable doubt as to Ms. Folbigg's convictions, and instead the only reasonable conclusion open to him was that Ms. Folbigg smothered her children. He arrived at this conclusion despite the opinions of three eminent forensic pathologists that there was no evidence of smothering.

The above issues identified as resulting from the Commissioner's broad discretion limited the proper assessment and conclusions on the evidence available. Broad discretion in other inquiries might manifest in different ways; the central important point to be drawn from the above analysis is the lack of certainty around what is proper process in these forums. Without some legal

\footnotetext{
${ }^{180}$ See the letter from Professor Peter Schwartz to Professor Carola Vinuesa, online:

$<$ https://www.folbigginquiry.justice.nsw.gov.au/Documents/Exhibit\%20BT\%20-

\%20Letter\%20from\%20Professor\%20Peter\%20Schwartz\%20to\%20Professor\%20Carola\%20Vinuesa\%2 Odated\%2020\%20June\%202019.PDF>.

${ }^{181}$ See Lia Crotti et al, "Calmodulin mutations and life-threatening cardiac arrhythmias: insights from the International Calmodulinopathy Registry” (2019) 40:35 Eur Heart J 2964.

${ }^{182}$ Inquiry Report, supra note 106 at 507 [53].

${ }^{183}$ Ibid at 499-506.
} 
certainty and clarification as to the extent of the powers available to a decision maker, the process is not transparent, nor is it accountable. While discretion will always play a role in the law, as it should, the discretion ought to be proportional to the task.

\section{Independence, Transparency and Accountability in Ms. Folbigg's case}

From the above points it can be concluded that in Ms. Folbigg's case there were several difficulties which limited the assessment of evidence in relation to her convictions. From the outset, the process of reviewing her petition was ambiguous: no one knew what the Attorney General's office was doing to consider her petition. It took over three years for a decision to be granted, and no reasons were given for the delay. When an inquiry was announced, a Commissioner and Counsel Assisting were chosen with no reasons given to support their selection. When the Inquiry commenced, it was restrictive in its terms and, in many respects, it did not consider all available evidence, new evidence or even requested evidence that might have impacted on the overall assessment of the case.

Ms. Folbigg's case raises very important questions around the extent of independence, transparency, and accountability in the system of post-conviction review in NSW. The article now turns to consider an alternate model of review - a Criminal Cases Review Commission.

\section{The United Kingdom's Criminal Cases Review Commission}

This section of the article will outline briefly the operation of the United Kingdom Criminal Cases Review Commission ("UK CCRC").

The UK CCRC was the "world's first statutory, publicly funded body" responsible for review of alleged wrongful convictions. ${ }^{184}$ The high profile wrongful convictions of the Guildford Four (1974), the Birmingham Six (1975), the Maguire Seven (1976) and Judith Ward (1974) ${ }^{185}$ prompted a Royal Commission on Criminal Justice in 1991 ("the Runciman Commission") which found that the post-conviction review processes were "incompatible with the constitutional separation of powers as between the courts and the executive." ${ }^{186}$ It also revealed that Home Secretaries who were tasked with conducting post-conviction review ${ }^{187}$ were failing to refer potential wrongful convictions for review for political as opposed to legal reasons. ${ }^{188}$ It concluded in this regard that "it is neither necessary nor desirable that the Home Secretary should be directly responsible for the consideration and investigation of alleged wrongful convictions as well as being

${ }^{184}$ Hoyle \& Sato, supra note 10 at 12.

${ }^{185}$ United Kingdom Criminal Cases Review Commission, How it all Began, online:

<https://ccrc.gov.uk/how-it-all-began/>. See also Rebecca Bihler, Miscarriages in the British Legal System

- "The Guildford Four" and "The Birmingham Six" (Munich, Germany: GRIN Verlag, 2009); Chris Mullin, "Miscarriages of justice in the UK" (1996) 2:2 J Legis Stud 8.

${ }^{186}$ Runciman Report, supra note 16 at 162.

${ }^{187}$ A role almost identical in this respect to the role of the Attorney General in NSW.

188 See e.g., Michael Naughton, The Criminal Cases Review Commission (Basingstoke: Palgrave Macmillan, 2009) at 1 [Naughton]. 
responsible for law and order and for the police." 189 After a lengthy review of many facets of criminal justice operation, including post-conviction review mechanisms, the Runciman Report recommended the establishment of a Criminal Cases Review Commission and provided the framework for operation. ${ }^{190}$

In 1997 an independent body tasked with investigating alleged wrongful convictions was established. The UK CCRC has the power to compel documents from public bodies, interview new witnesses, re-interview previous ones, and obtain expert evidence on various matters. ${ }^{191}$ It predominantly investigates cases that have already been subject to court appeal(s) and those from which there might be new arguments and/or evidence that calls into question the applicant's conviction or sentence. ${ }^{192}$ If the UK CCRC finds there are sufficient grounds for a new appeal, it will refer it to the appeal court which must hear the matter. ${ }^{193}$ The test for determining if a referral should be made is if the evidence "raises a real possibility that the appeal court will overturn the conviction" or that the court will reduce the sentence. ${ }^{194}$ The UK CCRC does not have the power to quash a person's conviction or alter a sentence; only the appeal court can do that. Its job is to investigate and refer meritorious cases to the appeal court for consideration. The Commission can also be asked by the appeal court to investigate an issue for them. Providing advice on reforms is also part of the UK CCRC's mandate. ${ }^{195}$

The official UK CCRC website lays out what the Commission does, how it does it and who comprises the staff. It does not, however, provide every detail of exactly what it does in the process of review. For example, the public until recently had limited knowledge about how the Commission went about reviewing an application. A longitudinal study conducted by Professor Carolyn Hoyle and Associate Professor Mai Sato has done much to demystify the inner workings of the Commission. In their recent book, Reasons to Doubt: Wrongful Convictions and the Criminal Cases Review Commission, they provide new insights into the body's operations. ${ }^{196}$ For example, they reveal that the Commission has Formal Memoranda and Casework Guidance Notes to provide a template for Commission staff in how they approach review.

\footnotetext{
${ }^{189}$ Runciman Report, supra note 16 at 182 [10].

${ }^{190}$ Ibid at $180-8$.

${ }^{191}$ Criminal Appeal Act 1995 (UK) ss 15-22 [CAA].

${ }^{192}$ United Kingdom Criminal Cases Review Commission, What We Do, online: <https://ccrc.gov.uk/aboutus/what-we-do/>.

${ }^{193}$ Ibid.

${ }^{194} C A A$, supra note 191 at s 13 ; for judicial interpretation of what the test involves see $R v$ Criminal Cases Review Commission (ex parte Pearson), [1999] 3 All ER 498.

${ }^{195}$ Runciman Report, supra note 16 at 184.

${ }^{196}$ Hoyle \& Sato, supra at note 10.
} 
The UK CCRC has approximately 90 staff (which can vary from year to year):

1. There are 12 Commissioners who are responsible for whether cases can be referred to the appeal court. ${ }^{197}$ They are selected for their legal professional experience. ${ }^{198}$

2. There are around 30 Case Reviewer Managers who are responsible for screening and reviewing cases. ${ }^{199}$

3. There are around 5 Group Leaders; one Legal Advisor and one Investigations Advisor who oversee various functions in the Commission. ${ }^{200}$

4. There are around 30 Administrative and Executive Support staff, comprising of Nonexecutive Directors who are responsible for the provision of advice, constructive challenge and scrutiny of decisions and performance, ${ }^{201}$ and the Senior Management Team who are responsible for the day to day running of the Commission. ${ }^{202}$

Through the research by Hoyle and Sato, it was recognised that Formal Memoranda and Casework Guidance Notes are interpreted differently by staff members. Some Commission staff apply them more strictly than others, and some think there is still place for discretion and "gut instinct". Ironically there exists a Casework Guidance Note on gut instinct. ${ }^{203}$ Hoyle and Sato concluded that despite the guidance via Formal Memoranda and Casework Guidance Notes, there is still significant discretion applied in review actions and decisions. ${ }^{204}$ They observed that the Commission does not operate in a robotic way; there are other forms of knowledge shared and created within the Commission which play an important role in the review process. ${ }^{205}$ For example, Commission staff referred to the fact that they might seek assistance from a colleague who has expertise in an area. ${ }^{206}$

The following is a brief account of some of the key steps within the three stages of review from receipt of an application, to the decision of whether to refer a case to the appeal court:

197 Commissioners are appointed in accordance with the Office for the Commissioner for Public Appointments' Code of Practice. They work with the senior management team to ensure the Commission runs effectively.

${ }^{198}$ All of the Commissioners currently have experience in the legal industry, see the website for information on the 12 Commissioners: United Kingdom Criminal Cases Review Commission, Who we are, online:

$<$ https://ccrc.gov.uk/who-we-are/> [Who we are].

${ }^{199} \mathrm{Ibid}$; Hoyle \& Sato, supra note 10 at 6.

${ }^{200}$ Hoyle \& Sato, supra note 10 at 6.

${ }^{201}$ See, Who we are, supra at note 198.

${ }^{202}$ Ibid.

${ }^{203}$ Hoyle \& Sato, supra note 10 at 48.

${ }^{204}$ Ibid at 62.

${ }^{205}$ Ibid at 62.

${ }^{206}$ Ibid at 64 . 


\section{Screening Cases:}

- An application is reviewed for eligibility according to law and must raise either a fresh argument or evidence. ${ }^{207}$

- If an application is eligible, information is gathered to support review of the application. For example, documents from the applicant's trial and appeals (if applicable).

\section{Review of Cases:}

- Cases are organised in priority and allocated for review accordingly. ${ }^{208}$ Level 1 cases maximum 3 months to complete review; Level 2 within 26 weeks; Level 3 within 78 weeks. ${ }^{209}$

- Additional evidence required for consideration of the application is gathered.

- If expert evidence is an issue, the Commission decides when to seek expert opinion, what evidence to obtain, and who to select as an expert witness. At this stage, input from the applicant and their legal representative (if they have one) can be considered by the Commission.

- When reviewing information and collecting evidence, it is documented: what has been collected and why; how much time has been spent on a case; if other resources have been put to it; if there have been delays and why. ${ }^{210}$

\section{Decision making:}

- A decision-making committee is formed to discuss the relevant issues in a case.

- If there are grounds to refer the case to the appeal court, a minimum of three Commissioners must deliberate and decide on what grounds. ${ }^{211}$

- If the case does not meet the requirement for referral, a single Commissioner is able to approve this decision although she /he must be satisfied that all enquiries have been made and that the material available does not give rise to a "real possibility" that the conviction would be set aside by the Court. ${ }^{212}$

- When a decision not to refer is made, a Provisional Statement of Reasons is sent to the applicant which addresses the reasons for the decision and if further work is required by the Commission, it will outline this. ${ }^{213}$ The applicant is invited to make written submissions in reply.

Actions taken within the review stages are guided by Formal Memoranda and Casework Guidance Notes to assist the Commission staff in how to perform their role appropriately. The following are some of the Formal Memoranda that the Commission have: when to gather

\footnotetext{
207 The Casework Administrative Team is responsible to determine if the application is eligible for review by the Commission - they have regard to, inter alia, section 13 of the Criminal Appeal Act 1995 which sets out the test, as well as determining if the applicant has already appealed prior, see Ibid at 49-50.

${ }^{208}$ Ibid at 53.

${ }^{209}$ For example, in the case of Level 2 cases, the Commission achieved this target in 2015/2016 with a reported average time of just over 19 weeks and Level 3 cases an average of 55 weeks, see Ibid at 54 .

${ }^{210}$ Ibid at 60 .

${ }^{211}$ Ibid at 59.

${ }^{212}$ Ibid.

${ }^{213}$ Ibid.
} 
additional evidence; when to use medical records ${ }^{214}$ when to interview witnesses ${ }^{215}$ on communicating with applicants; ${ }^{216}$ to engage the investigating body to conduct a new review; ${ }^{217}$ on recording progress for each review; ${ }^{218}$ on post-decision activity; ${ }^{219}$ and, on timeframe for applicant to provide further submissions. ${ }^{220}$ Some Memoranda are more prescriptive than others; for example, the one on interviewing witnesses permits wide discretion to determine if the witness has something material to say; ${ }^{221}$ while others are flexible and open to interpretation. Hoyle and Sato observed that "the Commission engages in a series of routines around the collection and management of information as well as ritualized processes for constructing a Statement of Reasons to demonstrate to those outside the organisation that it follows fair, consistent and legitimate procedures." 222 The process of decision making is not linear or artificially constrained; it is about making the "right decisions" and finding the "best evidence.",223

When looking at the key measures of fairness in decision making, transparency and accountability are readily observed in several ways the Commission operates. The initial letter sent to the applicant to outline the Commission's understanding of the matter and to seek clarification about issues also appears to be a concerted effort at procedural fairness, which corresponds to the promotion of transparency and accountability. The same can be said for the invitation for the applicant to reply to the Provisional Statement of Reasons where a decision is made not to refer the case. While the Commission does not publicise on their website each process it takes to review a conviction, such as the Formal Memoranda and Casework Guidance Notes, their existence means that tracing any error in the review process is made easier by clear and tracked steps. The frequent communication with the applicant and the consultation with them on relevant matters (such as in the case of obtaining expert opinion) promotes transparency and accountability because the applicant is informed and involved in the process. The Statement of Reasons / Provisional Statement of Reasons also serves the purpose of "[accounting] for its decisions during investigations" 224 which also enhances transparency and accountability. The fact that such reasons can be used to challenge the Commission's actions, by way of judicial review, means that each step taken in the review process can be scrutinised for error. None of the above processes or practices are present in the NSW system, highlighting the comparable deficiency in transparency and accountability. Additionally, unlike NSW where usually an individual is responsible for decision making, the Commission has several people who are involved in the review process and a panel of Commissioners agree on the value of the case. This has the potential to both reduce the

${ }^{214}$ Ibid at 55 .

215 Ibid at 56.

216 The Formal Memoranda says that communication with the applicant is made at least once every three months while the review is in progress, see Ibid at 57.

217 The Formal Memoranda provides a non-exhaustive list of factors that can be taken into account by Commissioners when deciding whether to appoint an investigating officer, see Ibid at 58.

${ }^{218}$ Ibid at 61.

219 Ibid.

${ }^{220}$ Ibid.

${ }^{221}$ Ibid at 57.

${ }^{222}$ Ibid at 67.

${ }^{223}$ Ibid.

${ }^{224}$ Ibid at 49. 
error rate and to the remove the appearance and effect of bias, which is critical to ensuring the independence of the process.

Despite the reported success of the Commission to date ${ }^{225}$ and the model being implemented in other countries across the world, there are critics of the UK CCRC. ${ }^{226}$ One of the main reasons the UK CCRC was established was to provide independence for decision making. One main criticism that has been levelled at the Commission is the test used to determine if a case ought to be referred to the appeal court. It has been said that the "real possibility test" in effect means that there is an impermissible relationship between the UK CCRC and the appeal court; one of the very reasons why the UK CCRC was established. The UK CCRC, in using the test, needs to anticipate what the appeal court might decide. It has been said to lead to caution in referring cases which might go against the way the appeal court decides matters at the relevant time. Some critics contend that this means that the UK CCRC is "subordinate" to the appeal court, which is contrary to the vision for the body as outlined by the findings of the Runciman Commission. ${ }^{227}$ UK CCRC staff have said that they could be bolder in referring cases to the appeal court, ${ }^{228}$ an indication they agree to some extent with this criticism.

Additionally, other more specific criticisms have been made of the operation of the UK CCRC. Lawyers who have engaged with the UK CCRC claim it is not collecting all relevant documents, has failed to interview important witnesses and in some instances, misinterpreted the law. ${ }^{229}$ These criticisms raise important questions about the efficacy of the Commission; however, some must be approached with caution. Hoyle and Sato comment that some prima facie strong criticisms "have little empirical basis." 230

${ }^{225}$ See generally, annual reports, United Kingdom Criminal Cases Review Commission, Corporate Information and Governance, online: 〈https://ccrc.gov.uk/corporate-information-and-publications/>.

${ }^{226}$ See generally, Stephen Heaton, "Is the CCRC fit for purpose?", The Justice Gap, online:

<https://www.thejusticegap.com/is-the-ccrc-fit-for-purpose/>; see also various publications by Michael Naughton on this issue, especially Naughton, supra at note 188; another main criticism is a lack of appropriate funding, see Hoyle \& Sato, supra note 10 at 18-21.

${ }^{227}$ Michael Naughton, Comments on the work of the Criminal Cases Review Commission, online: <https://www.parliament.uk/globalassets/documents/commons-committees/Justice/02-A-MichaelNaughton-letter.pdf $>4$; for other considerations on whether the CCRC is in fact "subordinate", see Hoyle \& Sato, supra note 10 at 14-9 and Hannah Quirk, "Don't Mention the War: The Court of Appeal, the Criminal Cases Review Commission and Dealing with the Past in Northern Ireland" (2012) 76:6 Mod L Rev 949.

${ }^{228}$ Hoyle \& Sato, supra note 10 at 67.

${ }^{229}$ The Guardian, Miscarriages Of Justice Body Is Not Fit For Purpose, Lawyers Say, online: $<$ https://www.theguardian.com/law/2018/may/30/criminal-cases-review-commission-not-fit-for-purposelawyers-say> [The Guardian].

${ }^{230}$ Stephen Heaton, "A critical evaluation of the utility of using innocence as a criterion in the post conviction process", online: $<$ https://core.ac.uk/download/pdf/29106228.pdf $>$ at 97, cited in Hoyle \& Sato, supra note 10 at 13 . 
Now that this article has explored post-conviction review in NSW, the Folbigg case and how the UK CCRC operates, a critical comparison will be provided. This is done by way of a hypothetical working through of how Ms. Folbigg's case might have been handled by the UK CCRC.

\section{NSW v UK: How Do the Systems Compare?}

While some critics say the UK CCRC is not as effective as was initially hoped, even taken at its worst, it is a vast improvement on the way in which NSW conducts post-conviction review. This is because it is designed to conduct review in an independent, transparent, and accountable way. The UK CCRC was established because of the inadequacy of the former post-conviction review system, a system nearly identical to that in NSW at present. To illustrate the difference between the systems, the following brief account will be provided to illustrate how Kathleen Folbigg's matter might have been dealt with by the UK CCRC (integrating some of the known facts about her case and what occurred in the review of her convictions).

In June 2015, Ms. Folbigg's application for review would have been received by the UK CCRC. This application would have either been completed by her or her legal representatives. She could have filled out the easy-to-read application form on the UK CCRC's website. At the initial stage - the Screening Stage - it would have been decided that there was a real possibility that the appeal court would not uphold her convictions because there was never any pathological evidence of smothering and only natural causes of death at the autopsy for each child.

Her matter would likely have been assigned Level 2 priority, and an outcome would have been provided within 26 weeks (mainly because she is incarcerated and has been for a significant period). She might have argued for Level 1 priority because delay in consideration of her case was likely to have a significant effect on the criminal justice system; it could reveal a serious wrongful conviction and an expedited review was required to avoid any additional time incarcerated. ${ }^{231} \mathrm{In}$ any event, the outcome would have been received within 26 weeks, a stark contrast to over three years in her case in NSW. At this stage, the Commission would have sent Ms. Folbigg a letter advising what they understood her case to entail. After this initial contact they would have communicated with her once every three months to update her about her case, and if applicable, request her input on certain matters. All steps taken in the review would have been documented by each staff member involved.

The Case Review Managers would have then gathered relevant evidence, for example, all the trial transcripts, appeal judgements, health records from the state, and any other relevant information required to understand the issues. This would have been guided by the Formal Memoranda on when to gather evidence and when to use medical records.

At the Review Stage the central issues would have been identified and a decision made about what further information might be required. Because the cause of death of the children was the central issue, the CCRC might have interviewed the forensic pathologist to explain why the

${ }^{231}$ Hoyle \& Sato, supra note 10 at 54. 
cause of Laura Folbigg's death was recorded by him as "undetermined". The Commission might have sought an opinion from a forensic pathologist not involved in determining the diagnoses of the children (similar to that provided by Professor Stephen Cordner), to provide an independent assessment of the pathology reports and materials for all the autopsies. Other expert opinion might have been sought to identify other relevant medical and scientific matters, for example, genetics or immunology. The Commission might also have interviewed the investigating officers who pursued the charges against Ms. Folbigg.

If expert opinion obtained supported natural causes of death for the children (not murder), at the decision-making stage, it would have been determined that a real possibility existed that the appeal court would not uphold Ms. Folbigg's convictions. ${ }^{232}$ This would be because Ms. Folbigg's convictions were based on the theory that she murdered her children by smothering them. A panel of three Commissioners would have then prepared a Statement of Reasons to refer her case to the appeal court and would have provided this to Ms. Folbigg.

Ms. Folbigg's case would then have been heard by the Court of Appeal. Due to the positive evidence of natural causes of death for each child, the Court would have concluded that the convictions are unsafe and have allowed the appeal. ${ }^{233}$

The above is a brief, hypothetical analysis of Ms. Folbigg's case based on what is known about the operations of the CCRC. In no way does this detail all the steps that would likely be taken, nor does it capture all the relevant issues in Ms. Folbigg's case. For example, it only focuses on the pathology of the children, not issues relating to her diaries. There would, no doubt, be discretion used by staff members in the different levels of review. The scenario is important because it illustrates a defined process. The fact that one can produce a likely step by step analysis of how this case might be dealt with at the CCRC illustrates that the process is transparent.

\section{Recommendations}

If the overall aim of post-conviction review is to uncover wrongful convictions and remedy them, all three key elements of independence, transparency and accountability must be present. A fundamental deficiency in any one of them might compromise the fairness of the outcome for an applicant.

Because of the inherent deficiencies in the NSW system, political factors might influence the impartial assessment of serious convictions. A very similar debate around a lack of independence when the Home Secretary, the United Kingdom's equivalent to the Attorney General in this context, oversaw post-conviction review was formative to the establishment of the UK CCRC. At present, there is very little independence in the process of post-conviction review in NSW. Transparency is also lacking in the system. There is currently no publicly available information regarding how executive actors in NSW make decisions. Do they engage expert opinions? Do they seek advice from the prosecution? Do they ask the police to reinvestigate? Do

${ }^{232}$ CAA, supra note 191 at s 13(1)(a).

${ }^{233}$ Ibid s 2. 
they interview witnesses or re-interview previous ones? Does the applicant have the opportunity to comment on material that is adverse to them? These are all relevant actions where applicable, although it is uncertain if these are occurring in the review process. The lack of transparency in the way review is conducted by executive actors corresponds to a lack of accountability. When the public is unaware of how a decision is being made and by whom, there can be very little meaningful accountability. To make matters worse, people who alleged they have been wrongfully convicted are unable to surpass even the first hurdle - applying for review. They have no guidance about how to prepare a review or what matters the decision makers will be considering. This is a significant issue for access to justice. A lack of assistance in this regard is highly likely to mean that wrongfully convicted individuals will not apply in the first place.

In contrast to the NSW system, much is known about how the UK CCRC operates. The debate about a lack of sufficient separation between the UK CCRC and the appeal court, by way of the referral test, might have merit. In that case, UK CCRC might consider reforming the test used to ensure that the UK CCRC is not simply predicting how the current appeal court might act and is acting on their opinions of merit. ${ }^{234}$ In terms of transparency, the UK CCRC is exemplary in comparison to NSW. The website is clear, accessible, and informative. It provides an easy-toread application form designed to be accessible to people without legal training. The public is aware who comprises the UK CCRC, what they do (and cannot do), why they do it and how. The research by Hoyle and Sato has further enhanced the public's awareness of the Commission's role. There are timeframes in which an applicant can expect to receive a decision. For consistency in review, Commission staff are guided at each stage of the review process through Formal Memoranda and Casework Guidance Notes. In summary, the UK CCRC is structured to: avoid political factors influencing its impartial assessment of cases; stage the review process to permit a wider perspective of the issues in the case; conduct the review in a transparent way guided by defined processes; conduct reviews within targeted timeframes. The above features of the CCRC promote transparency and accountability.

This article recommends that NSW establish a Criminal Cases Review Commission. It does not, however, recommend a wholesale adoption of the UK CCRC. One chief consideration is the need to devise a sufficiently appropriate test that a Commission in NSW might use to refer cases to the Court of Criminal Appeal. It would also need to ensure that appropriate funding would allow the Commission to ensure matters are dealt with in a timely manner not at the expense of thoroughness. Most of the operations of the UK CCRC would be appropriate to a Commission in NSW. Many of the issues that arise in relation to wrongful convictions traverse national borders; these include prosecutorial misconduct and unreliable forensic evidence. Such matters are covered in Formal Memoranda and Casework Guidance Notes which could be adapted by any Commission.

\footnotetext{
${ }^{234}$ It has been suggested that a preferable test might be along the lines of "i.e., a test that requires the CCRC and the court of appeal to consider holistically whether a miscarriage of justice may have occurred for whatever reason.", see The Guardian, supra at note 229.
} 


\section{Conclusion}

Legal systems across the world will always experience wrongful convictions: the simple fact is legal systems are human institutions and are fallible. As Hoyle and Sato aptly describe: "[i]n all Western democracies, appeals processes may fail to identify wrongful convictions: appeals solicitors do not have adequate resources to investigate cases; judges fail to recognize when the system has erred; or at the time of direct appeal forensic science was insufficiently developed to be of probative value." ${ }^{235}$ Just because wrongful convictions will always feature as a by-product of criminal legal systems, it does not mean that reform to post-conviction review is a fruitless endeavour. Criminal legal systems across the world should be aware that wrongful convictions do occur and commit to make changes to processes that are possible and appropriate. When wrongful convictions are identified, they should be taken as an opportunity to improve the system.

NSW is lagging behind its common law counterparts in the area of post-conviction review. ${ }^{236}$ As recently as 2020, New Zealand adopted a Criminal Cases Review Commission to move away from having responsibility lie with the executive government. NSW is in a unique position; it has the benefit of learning from the decades of collective knowledge gained from countries who have also adopted this pioneering model. The experiences gained from similar bodies in other countries - subject to scrutiny and review for decades now in the case of the United Kingdom - mean that NSW could create best practice by devising a model which takes into account criticisms of other Commissions. A wholesale adoption of the United Kingdom's model is not the answer; NSW should be concerned to have the most independent, transparent, and accountable processes realistically possible suitable to the domestic context. The establishment of a Commission should give the NSW public confidence that the criminal legal system not only takes seriously the issues of wrongful convictions, but it also gives certainty to the way the system corrects its own mistakes. Without such reform, wrongful convictions will go undiscovered and unremedied, which is nothing short of a "searing injustice" ${ }^{237}$ for both the convicted person and our society.

\footnotetext{
${ }^{235}$ Hoyle \& Sato, supra note 10 at 6.

${ }^{236}$ See generally on the need for reform in Australia, Michael Kirby, "A new right of appeal as a response to wrongful convictions: is it enough?" (2019) 43 Crim LJ 299.

${ }^{237}$ Van der Meer, supra at note 2.
} 